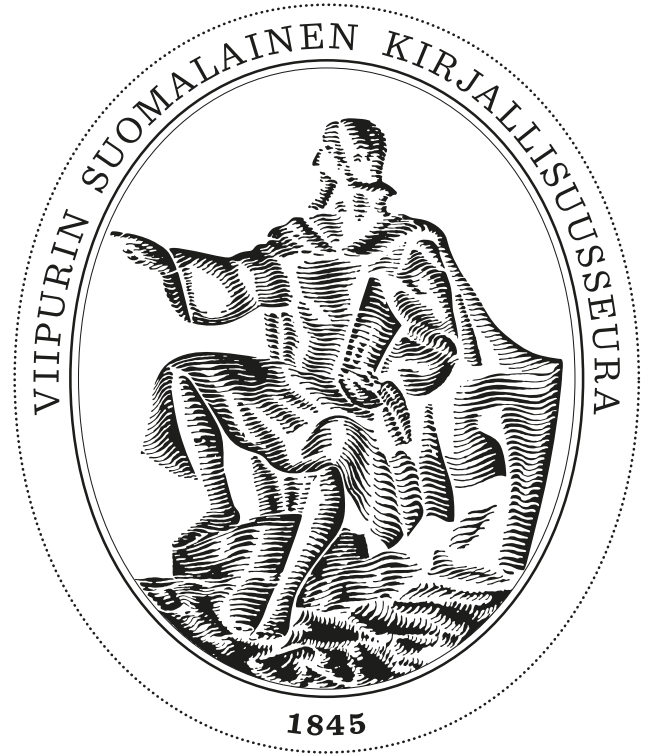

VIIPURIN SUOMALAISEN

KIRJALLISUUSSEURAN

TOIMITTEITA

(18)

Muuttuvien tulkintojen Viipuri 
Kansikuva: Osa Severin Falkmanin vuonna 1886 tekemästä öljymaalauksesta Kaarle Knuutinpoika Bonde lähdössä Viipurin linnasta Tukholmaan kuninkaanvaaliin 1448. Karl Knutson Bonde på väg från Viborgs slott till kungavalet i Stockholm 1448.

Kansallisgalleria/Kirsi Halkola. Ateneumin taidemuseo.

Viipurin Suomalaisen Kirjallisuusseuran Toimitteita osa 18 Muuttuvien tulkintojen Viipuri

Toimittaneet:

Anu Koskivirta (osan päätoimittaja),

Pentti Paavolainen (sarjan päätoimittaja),

Sanna Supponen (sarjan toimitussihteeri)

Kuvatoimitus:

Risto Marjomaa

Graafinen suunnittelu \& taitto:

Eemeli Nieminen, www.eemelinieminen.fi

ISBN: 978-952-67216-3-7 (Toimite 18, PDF)

ISSN: 1236-4304 (Sarja)

Painettu: 2016, Juvenes Print

Painosmäärä: 200 kpl

2. korjattu painos.

Julkaisija: Viipurin Suomalainen Kirjallisuusseura, Helsinki 


\section{Talouden ehdoilla: aineellisen ja henkisen kulttuurin vuorovaikutus Viipurissa 1500-1600-luvuilla}

\section{JOHDANTO}

Artikkelissa tarkastellaan Viipurin aineellisen ja henkisen kulttuurin vuorovaikutusta Vaasa-kaudelta aina suurvaltakauden lopulle (n. 1520-1710). Tavoitteena on antaa yleiskuva kyseisen ajanjakson päälinjoista sitomalla viipurilainen todellisuus Ruotsin valtakunnan yleiseen kehitykseen. Esitys selvittää aineellista kulttuuria niin normien ja rakenteiden kuin paikallisten toimijoidenkin näkökulmasta. Pääpaino on taloudellisten reunaehtojen analyysissä, joka auttaa suhteuttamaan Viipurissa varsinkin 160o-luvun kuluessa tapahtunutta henkisen kulttuurin kehitystä.

Aineellisen ja henkisen vuorovaikutus merkitsee seuraavassa prosessia, jossa taloudellinen kasvu ja vauraus loivat edellytyksiä erilaisten henkisten kulttuurimuotojen kehittämiseen ja kehittymiseeen. Kulttuuri ymmärretään kaikeksi ihmisen tuottamaksi toiminnaksi, joka ei ole taloutta; talous tavallisimmin mahdollistaa kulttuurin ja on jopa välttämätön sen muodostumisen taustatekijä. Uskoakseni käsitys vastaa ankarasti yksinkertaistettunakin tutkimuskauden viipurilaisten ajatusmaailmaa.

Valittu näkökulma ohjaa tarkastelun lopuksi aikakauden Viipuria käsittelevään kirjallisuuteen, historiakulttuuriin, historian käyttöön ja historiakuvaan. Näistä teemoista on viimeisten vuosikymmenten aikana tehty kansainvälisesti runsaasti tutkimusta, mutta Suomessa tutkimus on ollut vielä vähäistä.' Esimerkiksi historiakuvan luomisesta käy Viipurin viimeisen suomalaisen kaupunginjohtajan Arno Tuurnan luonnehdinta "Viipurin psyyken" osatekijöistä Viipurin kirjassa (1958). Hänen mukaan Viipurin tunnettu erityisyys koostui 1) kaupungin ja linnan etuvartioasemasta suhteessa itään, 2) kaupungin "luonteesta", joka näkyi "viipurilaisten avaramielisyytenä ja suvaitsevaisuutena suhteessa toinen toisiimme", 3) "Viipurin omalaatuisesta kulttuurista", 4) "hartaasta uskonnollisesta mielestä" sekä 5) Viipurin linnasta. ${ }^{2}$

Monet näistä erityispiirteinä pidetyistä seikoista ovat sittemmin nousseet Viipuri-muistoissa ja tutkimuksessakin keskiöön. Osa teemoista tavataan 1500- 


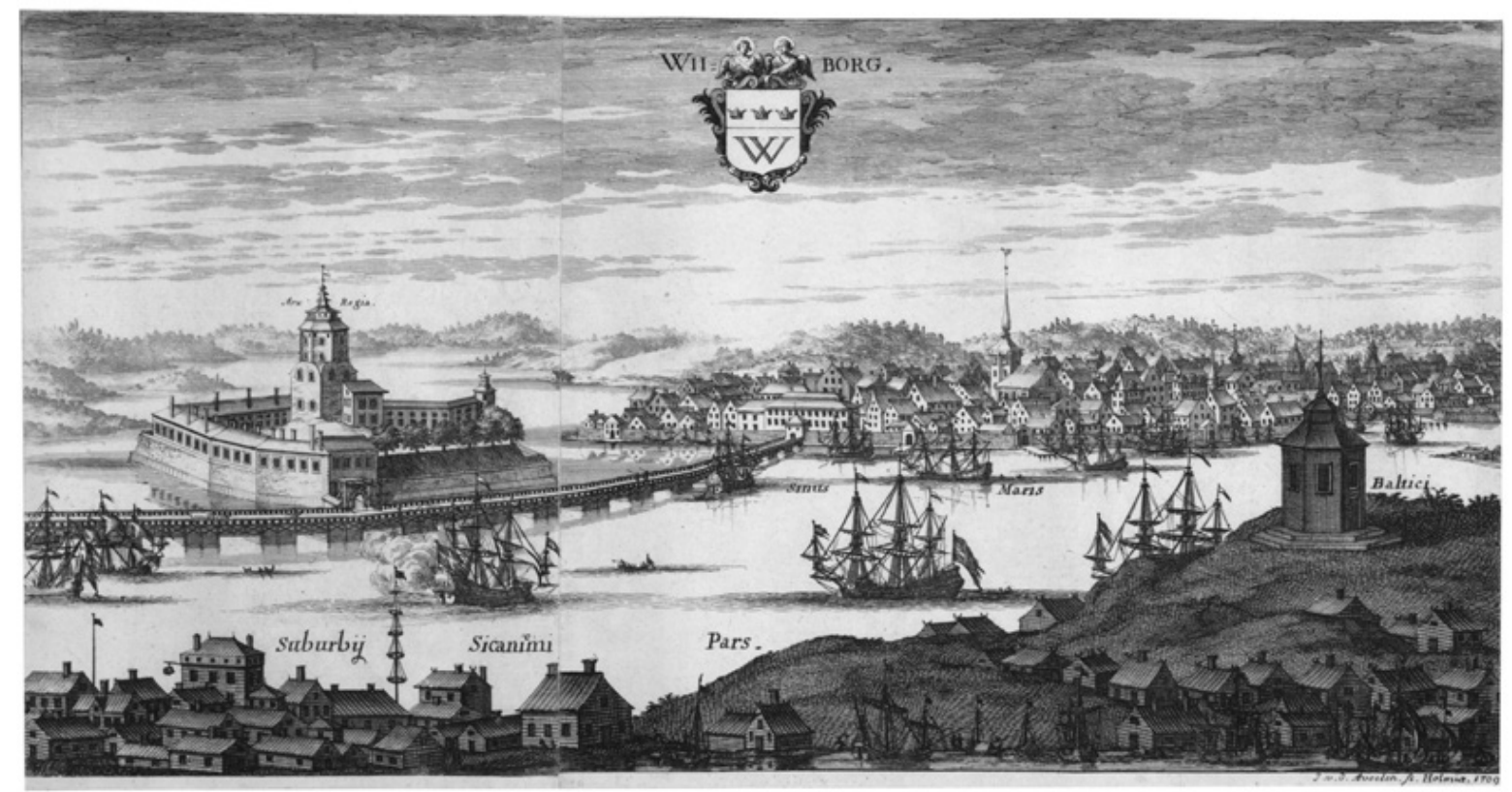

Viipurin kaupunki ja linna 1600-luvun jälkipuoliskon asussaan Erik Dahlberghin Suecia Antiqua et Hodierna -teoksen perusteella.

ja 16oo-luvun Viipurista. Linna ja kaupunki muodostivat Ruotsin valtakunnan

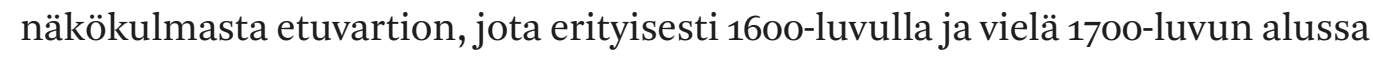
kutsuttiin näkökulmasta ja ajankohdasta riippuen Karjalan lukoksi, Suomen lukoksi tai jopa Ruotsin lukoksi. Viipuri oli myös yksi kolmesta Ruotsin linnoitetusta kaupungista: kaksi muuta olivat samalla tavoin pitkään rajakaupunkina seissyt Kalmari sekä pääkaupunki Tukholma. ${ }^{3}$ Kaupungin valta-asema Ruotsin valtakunnan itäisen osan taloudellis-poliittisena keskuksena oli ehdoton aina 170o-luvun alkuun. ${ }^{4}$ Sen sijaan vaikeammin todennettavia ovat tutkimustiedon perusteella ennen muuta kohdat $2-4$.

Artikkeli alkaa talouden ja oikeuksien mahdollisen rajojen esittelystä. Sen tarkoituksena on havainnollistaa, kuinka aineellisen kulttuurin kehittymiselle tärkeät seikat, kuten kaupungin status, ranki, erioikeudet ja -vapaudet, luovat yleisen taustan Viipurin asukkaiden ja sen eri ryhmien toimintakyvyn ymmärtämiselle. Taloudelliset reunaehdot ja käytäntö puolestaan kytkeytyvät suoraan paikallisen poliittisen kulttuurin kannalta keskeiseen vuorovaikutukseen hallitsijan kanssa. Hallitsijaan vetoamalla porvaristo pyrki hankkimaan itselleen, edustamalleen ryhmälle ja kotikaupungilleen entistä parempia etuja ja oikeuksia. Tämän jälkeen tehdään katsaus kaupungin yleiseen ilmeeseen ja infrastruktuuriin. Lopuksi pohditaan muun muassa lineaarista - kaupunkimaista - aikakäsitystä, joka vaikuttaa monenlaisiin kaupunkikulttuurin ulottuvuuksiin "poikkeavuuksien" kuvauksista koulutuksen, sivistyksen ja taiteen merkitykseen yhteisössä. 


\section{VIIPURIN LÄHDEAINEISTO JA AIKAISEMPI TUTKIMUS}

Esitys perustuu pääosin aikaisempaan tutkimukseen ja sen osittaiseen uudelleentulkintaan, mutta tekstin tausta-aineistona on käytetty runsaasti alkuperäisaineistoja. Viipurin linnan- ja tullitilit sisältävät suuren määrän yksityiskohtaista tietoa 1500-luvun puolimaista alkaen, ${ }^{5}$ ja myöhemmin Viipurin läänin aineistoissa (n. 1640-1710) on jonkin verran kaupunkiin liittyviä dokumentteja, kuten hajanaisesti säilyneitä kaupungin tilejä. Silti tärkein kertova aineisto sisältyy kaupungin monipuoliseen ja 1620-luvulta aina Ruotsin ajan lopulle säilyneeseen tuomiokirja-aineistoon. Viipurin tuomiokirjat - jotka käsittävät sekä alempana tuomioistuimena toimineen kämnerinoikeuden että tärkeimmistä asioista ja hallinnosta vastanneen raastuvanoikeuden pöytäkirjoja - ovat sisällöltään ja muodoltaan ainutlaatuisia Ruotsin valtakunnassa. Vaikka Viipurissa pöytäkirjoissa keskityttiin 1630-luvun alusta lähes yksinomaan oikeuslaitokselle oleellisten tietojen ja asioiden esittelyyn, voi juuri siksi kaupungin aineistolla tavoittaa monipuolisesti yksittäistenkin kaupunkilaisten ajattelua. Siinä mielessä Viipurin oikeudenkäyntipöytäkirjojen rikkaan annin voi rinnastaa yksityisaineistoihin, joita ei ole aikakauden suomalaisista kaupungeista juurikaan säilynyt. ${ }^{6}$

Monissa keskus- ja kirkollishallinnon sekä koululaitokseen liittyvissä lähdejulkaisuissa ja tietokannoissa on runsaasti aineistoa Viipurista. Sen systemaattinen hyödyntäminen on aiemmin jäänyt vähälle, mikä osin johtuu siitä, että aiempi tutkimus on pääosin tehty ennen tietokantojen julkaisemista. Joka tapauksessa esimerkiksi Kustaa Vaasan registatuura (1521-1560) sekä monipuolisesti Ruotsin valtakunnan kaupunkien suhdetta esivaltaan käsittelevä Privilegier, resolutioner och förordningar för Sveriges städer -sarja ovat tärkeitä apuvälineitä niin kaupunkihistoriassa yleensä kuin esimerkiksi kulttuurihistoriallisissa kysymyksissä. Tärkeitä kulttuurihistoriallisia näkökulmia sisältyy esimerkiksi Viipurin tuomiokirkon 160o-luvun lähdejulkaisuna painettuihin tiliaineistoihin. Sosiaali- ja henkilöhistoriallisesti merkittävä on verkossa vapaasti saatavilla oleva ylioppilasmatrikkeli, joka rekisteröi käytännössä kaikki suomalaiset ylioppilaat vuodesta 1640. Kulttuurihistoriallisesti tärkeä on esimerkiksi Toini Melanderin toimittama bibliografia suomalaisista varhaismoderneista pienpainatteista. Kiinnostavaa, joskin toisinaan vaikeasti avautuvaa ja käytettävääkin aineistoa ovat Viipuri-tutkijoiden omat yksityisarkistot. Gabriel Laguksen ja Kaarle Soikkelin yksityisarkistoja säilytetään Mikkelin maakunta-arkistossa, Ragnar Rosénin arkisto on Kansallisarkistossa ja J. W. Ruuthin yksityisarkistoja on sijoitettu sekä Kansallisarkistoon että Helsingin kaupunginarkistoon. ${ }^{7}$

Ruotsin ajan Viipurin historiantutkimus on kaupungin merkitykseen nähden yllättävän vähäistä. Kaupunkia kokonaisuutena käsittelevä tutkimus pe- 
rustuu 1800- ja 1900-luvun vaihteessa laadittuihin, sinänsä korkealuokkaisiin Gabriel Laguksen ja J. W. Ruuthin kaupunki- ja sukuhistorioihin. Ruuthin teosta päivitettiin sittemmin 1970-1980-luvulla, ja esimerkiksi suurvalta-ajan osuutta modernisoi kaupunkihistorian asiantuntija Aimo Halila. Silti tuossakaan osassa ei suuria muutoksia tehty, vaikka hallintohistorian osuus kasvoikin hieman ja sotahistoria paljon. ${ }^{8}$ Viipurin 700-vuotisjuhlan vaiheilla ilmestyi kaksi sinänsä vahvaa yleisesitystä kaupungin historiasta, ${ }^{9}$ eikä unohtaa voi jo vuonna 1958 julkaistua Viipurin kirja -muistojulkaisua, jossa varsinkin Viljo Nissilän artikkelit luovat hyvän yleiskatsauksen kaupungista. ${ }^{10}$ Kuitenkaan perustulkinnat eivät ole olennaisesti muuttuneet. Korkealuokkaisessa Viipurin läänin historiassa (III) tutkitaan monia kaupungin talouteen ja rakenteisiin vaikuttavia tekijöitä, mutta teoksen painopiste on nimensä edellyttämällä tavalla silti muualla kuin urbaaneissa tiloissa."

\section{PRIVILEGIOT, ETUOIKEUDET JA ERITYISVOITONPYYNTI KAUPUNGIN TALOUDELLISEN TOIMINNAN MAHDOLLISTAJINA}

Edellä on tullut ilmi, kuinka yhtä aikaa otollisella ja vaarallisella paikalla Viipuri ja siihen suoraan yhteydessä oleva linna sijaitsivat: Ruotsin ja Novgorodin, sittemmin Venäjän, rajaseudulla. Kaupungin olemassaolo ei Ruotsin valtakunnassa ollut koskaan itsestäänselvyys eikä yksinomaan kaupunkilaisten käsissä. Ruotsin erityispiirre suhteessa moniin muihin aikakautensa valtioihin oli nimenomaan siinä, että kaupungit olivat poliittisesti, taloudellisesti ja juridisestikin riippuvaisia kulloisestakin hallitsijasta. Niinpä Ruotsin kaikki kaupungit on tosiasiassa perustettu hallitsijan mahtikäskyllä, yksikään niistä ei ole syntynyt itsestään. ${ }^{12}$

Valtio eli hallitsija eli kuninkaallinen majesteetti jakoi erityisesti Kustaa Vaasan ajoista (hallitsijana 1521-1560) lähtien kaupungeille erilaisia etu- ja erioikeuksia. Privilegiotyyppejä oli monenlaisia, mutta tässä yhteydessä niistä kiinnostavimpia ovat valtion yliherruusasemansa perusteella taloudelliseen toimintaan - yleensä sekä kauppaan ja teollisuuteen - myöntämät monopolit, taloudelliset privilegiot, verovapaudet ja muut erioikeudet. ${ }^{13}$

Merkittävimpiin yleisiin erioikeuksiin kuuluivat kaupan keskittäminen kaupunkeihin (porvaristolle) sekä kaupunkien jakaminen tapuli- ja maakaupunkeihin. Jälkimmäisen nojalla osa kaupungeista suljettiin ulkomaankaupasta. Tapulipolitiikkaa sovellettiin ensimmäisen kerran vuosien 1614 ja 1617 kauppaja purjehdussäännöissä, joissa kaupungeille annettiin joko aktiiviset, passiiviset tai täydet tapulioikeudet. Maakaupungeilta ulkomaankauppa oli kielletty, sillä oman kauppapiirin sisäisen kaupan lisäksi porvareiden oli matkustettava 
joko lähimpään tapulikaupunkiin tai Tukholmaan. Viipurille myönnettiin täydet tapulioikeudet, joista se piti kiinni aina Ruotsin ajan loppuun. ${ }^{14}$

Hallitsijan Viipurille myöntämät erioikeudet eivät silti tarkastelujaksolla useinkaan sisältäneet yksityiskohtaisia määräyksiä. 1400-luvun ja 1500-luvun alkupuolen harvoissa asiakirjoissa vain todetaan ja vahvistetaan Viipurin kaupunkioikeudet, minkä lisäksi hallitsijat antoivat muutaman kerran asukkaiden suojaksi tarkoitettuja turvakirjeitä. Varsinaisia konkreettisia esimerkkejä viipurilaisten erityisasemasta suhteessa esimerkiksi ympäröivään maaseutuun on niukasti. Viipurin privilegiot olivat sananmukaisesti paperinohuet, mutta ajan myötä kaupunkilaiset osasivat venyttää ja vahvistaa niitä. ${ }^{15}$

Tilanne muuttui Kustaa Vaasan hallintokaudella, kun uskonpuhdistuksen myötä kuningas sai enemmän resursseja käyttöönsä ja kovensi äänenpainoaan. Vuonna 1537 hallitsija määräsi viipurilaisten valitusten perusteella voutinsa rankaisemaan laitonta maakauppaa harjoittaneita sotilashenkilöitä, sillä kauppaa sai käydä vain kaupungeissa. Tämä oli ensimmäinen kerta, kun viipurilaiset valittivat elinkeinonharjoitukseensa nivoutuvasta ja kaupungin etuoikeuksien suojaamiseen tähdänneestä asiasta. Myöhemmin Kustaa Vaasa antoi vastaavanlaisia määräyksiä lisää, mikä yhtäältä kertoo, että viipurilaiset olivat saaneet kanavat auki hallitsijan suuntaan ja toisaalta todistaa hallitsijan käskyjen tehottomuudesta. ${ }^{16}$

1540-luvun alussa Viipurin asema Ruotsin valtakunnan itäisimpien osien kaupallisena valtiaana viimein virallistui. Tuolloin Kustaa Vaasa antoi ensimmäisen avoimen kirjeensä, jossa hallitsija lupasi kaupunkilaisille sekä tavanomaisesti suojelustaan että yksinoikeuden kauppaan (Ruotsin) Karjalassa. Lisäksi viipurilaiset saivat muun muassa vapaamarkkinat Jääskessä, Lapvedellä (nyk. Lappeella), Äyräpäässä ja Vehkalahdella. Kuningas määräsi samalla, että Viipurin linnanisännän tuli lakkauttaa suurin osa lähimaaseudun "turhista krouvareista", jotka olivat kirjeen mukaan harjoittaneet maakauppaa ja muuta viipurilaisille epäedullista liiketoimintaa. Viipurin asema laillisena huvittelupaikkana vahvistui merkittävästi, kun alkoholin myynti maaseutupitäjissä tuli rajata vain muutamille henkilöille. Edelleen kuningas rajasi talonpoikien aiemmin varsin vapaata purjehdusoikeutta ja käski maalaiset viemään tuotteensa yksinomaan Viipuriin. Myöhemmin vuosikymmenen mittaan samankaltaisia määräyksiä annettiin useita, ja ainakin periaatteessa Viipurin asema valtakunnallisena satamakaupunkina koheni vuonna 1547, kun Tukholman ja Gävlen porvarit velvoitettiin Riian, Narvan ja Tallinnan sijasta purjehtimaan Viipuriin. Tosin näyttöä käskyn toimeenpanosta tai edes osittaisesta noudattamisesta ei ole. ${ }^{7}$

Kustaa Vaasa halusi kehittää Viipurista vuosisadan puolimaissa merkittävän Venäjän kaupan solmukohdan, mutta tuo ajatus - kuten monet muukin hallit- 
sijan nopeasti vaihtuvista suunnitelmista - oli lähtökohdiltaan toivoton. Myös Suomen herttua Juhana (herttua vuosina 1556-1563) pyrki omalla tahollaan edistämään Viipurin kaupallista asemaa vuonna 1562. Tuolloin hän kirjoitti Viipurin linnanisännälle Ruotsin valtakunnalle haitallisesta Käkisalmen venäläisten laittomasta kaupasta Norrbotteniin, joka tuolloin kattoi nykyisen Norrlannin ja Pohjanmaan. Herttua ideoi - isänsä aiempia aivoituksia mukaillen - Viipuria tällaisen kaupan risteysasemaksi, jonne Käkisalmen alueen asukkaat veisivät tuotteensa. Viipurilaisten tehtäväksi puolestaan tuli välityskauppa Norrbotteniin. Ajatus oli täysin epärealistinen; viipurilaiset itse suuntasivat samaan aikaan entistä enemmän Itämeren eteläosiin ja jopa Juutinrauman länsipuolelle, eivät Pohjanlahdelle tai Suomenlahden länsirannikolle. Oleellista tässä yhteydessä on silti se, että Viipurin asema Ruotsin valtakunnan itäisenä talouskeskuksena vahvistui ainakin ideatasolla. ${ }^{18}$

Vaikka suunnitelmat ulkomaankaupan suuntaamisesta Viipuriin jäivätkin paperille, kotimaankaupan tarkkarajaisen määrittelyn myötä Viipurin arvostus nousi eikä ohjeiden periaatteellinen merkitys jäänyt lainkaan yhtä mitättömäksi. Viipurin kaupunki ja koko Ruotsin valtakunnan itäinen rajaseutu kärsivät suuresti 25-vuotisesta Venäjän sodasta (1570-1595), joka ajoittaisista pitkistä aselevoista huolimatta sai aikaan karmivaa jälkeä niin Ruotsin kuin Venäjän alamaisten parissa. Anssi Mäkisen mukaan sodan aikana Savo ja Viipurin Karjalan maaseutu autioituivat noin 50-75-prosenttisesti, mutta Käkisalmen läänissä veronmaksukyvyttömyys tai äärimmillään fyysinen autioituminen nousivat 75-100 prosenttiin taloluvusta. Viipurille asia oli vakava. Käytännöllisesti katsoen kaikkien sen luontaisten talousalueiden tuhoutuminen heijastui suoraan kaupungin elinvoimaan ja kykyyn tuottaa kulttuurin edistämiseen tarvittavia taloudellisia resursseja. Tosin mainitun sodan kuluessa Viipurin linnaan ja lähiseuduille sijoitettiin runsaasti armeijan yksiköitä ja sodanjohtoa, jotka aiheuttamiensa vitsausten ohella toivat porvaristolle ansaintamahdollisuuksiakin. ${ }^{19}$

Tätä vaikeaa taloudellista tilannetta vasten on tulkittava jo sodan alkuvaiheessa vuonna 1573 kuningas Juhana III:n käskykirje Viipurin käskynhaltija Anders Nilssonille (Sabelfana): viipurilaisten pyynnöstä hallitsija määräsi, että Venäjän sodan päättymiseen saakka sellaiset kaukana Karjalasta sijaitsevat pitäjät kuin Hollola, Sysmä ja Jämsä kuuluisivat Viipurin kauppa-alueeseen, koska "Wiiborgz lhän är mestdeelis förheriedt och affbränndt". Viipurilaisten anomuksesta tuli ennakkotapaus, jonka innoittamina kaupunkilaisista kehittyi taitavia vaatimaan erilaisia etuisuuksia kaupungilleen. ${ }^{20}$ Tätä taitoa voidaan kutsua erityisvoitonpyynniksi (rent seeking), jolla pyrittiin kiskomaan omalle ryhmälle, yhteisölle ja usein itsellekin vielä parempia etuisuuksia kuin mitä normaalin hallitsijavetoisen erioikeusjärjestelmän puitteissa oli tavallisesti 
mahdollista. Erityisvoitonpyynti eroaa kapitalismille ominaisesta voitonpyynnistä siinä, että sen avulla tavoiteltiin nimenomaan merkantilismin ja vahvan valtiojohtoisuuden ajalle tyypillisiä, kilpailijat jopa kokonaan markkinoilta ulossulkevia erityisoikeuksia ja monopolioikeuksia. ${ }^{21}$ Ruotsissa ja Suomessa alamaiset pystyivät vaikuttamaan valtiovaltaan painostamalla sitä valituksin ja anomuksin. Hallitus määräsi ehdottomasti päälinjoista, mutta silti asukkaat eivät vain nöyristelleet lakki kourassa maallisen esivallan edustajien edessä. Viipurissa tilanne oli usein aivan päinvastainen. ${ }^{22}$

Kaarle-herttua myönsi 1600-luvun alussa viipurilaisten kannalta tarkastelujakson tärkeimmät privilegiot, kun Viipurista oli lähetetty vuosisatojen vaihteessa edustaja hallitsijan luokse. Perinteiseen tapaan valtionhoitaja vahvisti kaupungin privilegiot, mutta samalla myönsi sodassa ja tulipaloissa kärsimään joutuneille alamaisilleen uusia etuuksia. Tässä yhteydessä kiintoisia ovat Täyssinän rauhan (1595) jälkeen hetkeksi rauhoittunutta itärajaa koskevat ja edelleen tiukennetut määräykset, joiden mukaisesti kauppa tuli suunnata yksinomaan Tallinnaan ja Viipuriin. Toisaalta viipurilaiset valittivat herttualle, että Kustaa Vaasan kaupungille osoittamilta kauppa-alueilta maalaiset suuntasivat tavaroineen suoraan Tukholmaan, Tallinnaan ja jopa Pohjanmaalle ja Kainuuseen. Herttua kielsi odotusten mukaisesti jyrkästi tällaiset laittomuudet, ja vaikkei käskyillä heti ollutkaan merkitystä, niin Ruotsin itärajan rauhoittuessa 1610-luvun kuluessa ja erityisesti tervakaupan edelleen vilkastuessa tilanne muuttui oleellisesti. Viimeistään tuolloin alkoi Viipurin todellinen nousu talousmahdiksi. ${ }^{23}$

Kustaa II Aadolf kutsui vuonna 1616 Helsinkiin koolle valtakunnan itäisen osan ongelmia pohtineet maapäivät. Jälleen kerran viipurilaiset olivat paikalla puolustamassa saavutettuja etujaan ja pyytämässä lisää oikeuksia jo näköpiirissä olevan Venäjän kanssa solmittavan rauhan varalle. Viipurilaiset saivat hallitsijalta lähes yksinoikeuden koko Käkisalmen läänin kaupankäyntiin, sillä viittaamalla paikallisen hallituksen edustajan, Käkisalmen läänin käskynhaltija Hans Jonssonin, väärinkäytöksiin talouselämän aloilla, kuningas kielsi käskynhaltijaa puuttumasta viipurilaisten ja seutukunnan asukkaiden väliseen kauppaan. Viipurilaisille annettiin myös yksinoikeus merkittäville Lappeenrannan markkinoille - kaikilta muilta säätyyn ja arvoon katsomatta osallisuus markkinoiden järjestämiseen kiellettiin ankarasti. Muiden kuin viipurilaisten luvaton kaupankäynti näet "vei leivän suusta heiltä [viipurilaisilta], joille oli annettu lupa käydä kauppaa". Jos edellä tarkasteltuja helmikuun 1616 asiakirjoja pitäisi kuvata parilla lauseella, niin ne olivat ehdottoman voimakkaasti viipurilaisten puolesta, ankarasti kaikkia muita vastaan. Helsingin maapäivien päätökset sinetöivät kaupungin nousun valtakunnalliseksi talousvaikuttajaksi. ${ }^{24}$ 
Viipurilaisilla oli jo aiemmin ollut taipumus esittää häikäilemättömiä vaatimuksia oman kaupunkinsa puolesta. Niinpä jo Turussa 1547 Suomen harvalukuisten kaupunkien edustajien kokouksessa viipurilaiset esittivät suunnitelmansa noin 300 asumattoman tontin käyttöön ottamiseksi. Kaupunki oli tuossa vaiheessa pahasti kärsinyt poismuutosta ja taloudellisista laskusuhdanteista. Viipurilaisten esitys oli selkeä: tonttimaa saataisiin tehokkaasti käyttöön, mikäli Tammisaaren, Porvoon ja Ulvilan asukkaat siirrettäisiin vahvistamaan Viipuria. Kustaa Vaasa ei kuitenkaan suostunut ehdotukseen, mutta todennäköisesti tästä hallitsija sai muutama vuosi myöhemmin ideansa, jolla vastaperustettu Helsinki (1550) olisi asutettu lakkauttamalla Rauma, Ulvila ja Tammisaari. Viipurilaiset eivät kuitenkaan unohtaneet ajatustaan, sillä pari vuosikymmentä myöhemmin he pyysivät - turhaan - samaa uudestaan Juhana III:Ita. ${ }^{25}$

Tällaisista kokemuksista viipurilaisten uskallus ja suoranainen röyhkeys omien asioidensa edistämiseen joka tapauksessa vahvistuivat, mikä näkyi entistä selvemmin kaupungille taloudellisesti hyvin suotuisalla 16oo-luvulla. Viipurilaiset aktivoituivat jälleen 1640-luvun lopulla. Tuolloin he vastustivat kahden muun suomalaisen tapulikaupungin Turun ja Helsingin ohella niin kutsutun Norrlannin tervakomppanian vientimonopolia. Tämä täysin tukholmalaisten hallitsema yhtymä sai vuonna 1648 hallitsijalta 20 vuoden ajaksi yksinoikeuden tervan ja pien vientiin Norrlannista, Pohjanmaalta, Suomesta ja Karjalasta - käytännössä privilegion piirissä olivat näin kaikki vähänkin merkittävät tervantuotantoalueet. Aluksi viipurilaiset kauppiaat jättivät säännön noteeraamatta ja jatkoivat tervanvientiä kuin mitään ei olisi tapahtunutkaan. Myöhemmin he yrittivät helsinkiläisten ja turkulaisten kanssa vaikuttaa hallitsijaan, jotta Suomen tapulikaupungeille haitallinen komppania lakkautettaisiin. Yhteisvalitukset tuottivatkin osin tulosta, sillä vuoden 1650 valtiopäivillä asetettiin komitea tutkimaan asiaa. Komitean suosituksesta järjestelmän pahimpia epäkohtia poistettiin, mutta tervakomppaniaa ei silti lakkautettu. Suomen tapulikaupunkien edustajat vetosivat hallitsijan myöntämiin tapulioikeuksiin, joiden valitettiin menettävän merkityksensä, kun tervakomppania määräsi Pohjanlahden itäpuolen tärkeimmän vientituotteen tuotantomääristä, myynnistä ja markkinoinnista. Viipurilaiset totesivatkin tervakomppanian privilegioiden vievän "hyvän osan kaupungin tapulioikeuksista". ${ }^{26}$

Kaikkein tehokkaimmaksi vaikuttamisen tavaksi 160o-luvullakin osoittautui paikan päälle meneminen - tai siellä pysyminen. Tukholmassa suunniteltiin 1688 uutta valtakunnallista kauppalainsäädäntöä, jolloin pääkaupungissa jo valmiiksi oleskellut Viipurin vastanimitetty kuninkaallinen pormestari Per Fremling kirjoitti alaisilleen jäävänsä valvomaan yhteisönsä etuja. Samalla hän pyysi kaupunkilaisilta avustusta asumiskuluihinsa kalliissa kaupungis- 
sa. Viipurin raastuvanoikeus kutsui kymmenkunta vaikutusvaltaista porvaria neuvonpitoon, jonka tuloksena pormestarille lähetettiin pikapostissa kulujen kattamiseksi peräti 100 riikintaaleria. ${ }^{27}$

Viipurilaiset pystyivät tehokkaasti hyödyntämään ruotsalaisen poliittisen kulttuurin osa-alueita. Myöhemmin 170o-luvulla, kun osa vanhoista viipurilaisista oli siirtynyt Ruotsin Suomen puolelle ja osa jäi edelleen kotiseuduilleen Venäjän keisarin alaisuuteen, näistä opituista keinoista oli suuresti hyötyä sekä porvareille itselleen että heidän yhteisöilleen. ${ }^{28}$

\section{KAUPPA VAURAUDEN LÄHTEENÄ}

Talouselämässä Kustaa Vaasa (kuninkaana 1521-1560) halusi aiempien esimerkkien mukaisesti laajentaa suoria kauppasuhteita Länsi-Euroopan merkittäviin merivaltoihin. Hän yritti henkilökohtaisesti johtaa ulkomaankauppaa, jonka tuli nimenomaisesti olla kuninkaallisen majesteetin kauppaa. Venäjän suuntaa oli Skandinaviassa pidetty tärkeänä jo Kalmarin unionin (1397-1521) aikana, eikä Ruotsin Kustaa Vaasalla ollut siihen paljon uusia keinoja, vaikkei yritystä puuttunutkaan: hetken aikaa Viipurista kaavailtiin idänkaupan keskusta. Vaikka suunnitelma ei loppujen lopuksi toteutunutkaan, oli se vakavammalla pohjalla kuin esimerkiksi hallitsijan haave tehdä vastaperustetusta (1550) Helsingistä vahva vastustaja Tallinnalle. ${ }^{29}$

Tallinna, Riika ja Narva olivat ylivertaisia kilpailijoita muille Itämeren itäosien kaupungeille, mutta Viipurinkin asema kansainvälisessä kaupassa parantui merkittävästi Täyssinän (1595) ja Stolbovan (1617) rauhanteoissa. Erityisesti Täyssinän rauhansopimukseen sisältyi määräyksiä, jotka antoivat Viipurille muodollisesti tärkeän roolin Venäjän kaupassa. Jo tuolloin kaupungin ulkomaankaupan painopiste oli silti siirtynyt oleellisesti länteen, sillä Viipuri oli 1500-luvun jälkipuoliskolla noussut eurooppalaiseen tietoisuuteen aikakauden nousevan vientituotteen, tervan, viejänä. Jos Kustaa Vaasan loppuaikoina (1558) tervaa oli rahdattu satamasta maailmalle alle kolme lästiä (3o tynnyriä), niin kolme vuosikymmentä myöhemmin lästejä lähti yli puolentuhatta. Jo tuolloin Viipuri lienee ollut valtakunnan merkittävin tervanviejä. ${ }^{30}$ Volyymien kasvu jatkui huimaavana 160o-luvullakin. Esimerkiksi vuonna 1647 yli puolet Ruotsin valtakunnan tervanviennistä - noin 4500 lästiä 8500 lästin kokonaisviennistä - lähti maailmalle Viipurista, ja kaupunki säilytti asemansa Ruotsin merkittävimpänä tervanviejänä vuosisadan lopulle saakka. ${ }^{31}$

Näillä näytöillä Viipuri oli yksi Ruotsin valtakunnan tärkeimpiä tapulikaupunkeja ja kuului merkittävimpien ulkomaankauppaa käyvän kaupungin joukkoon Tukholman, Norrköpingin, Kalmarin ja Göteborgin sekä Tallinnan 


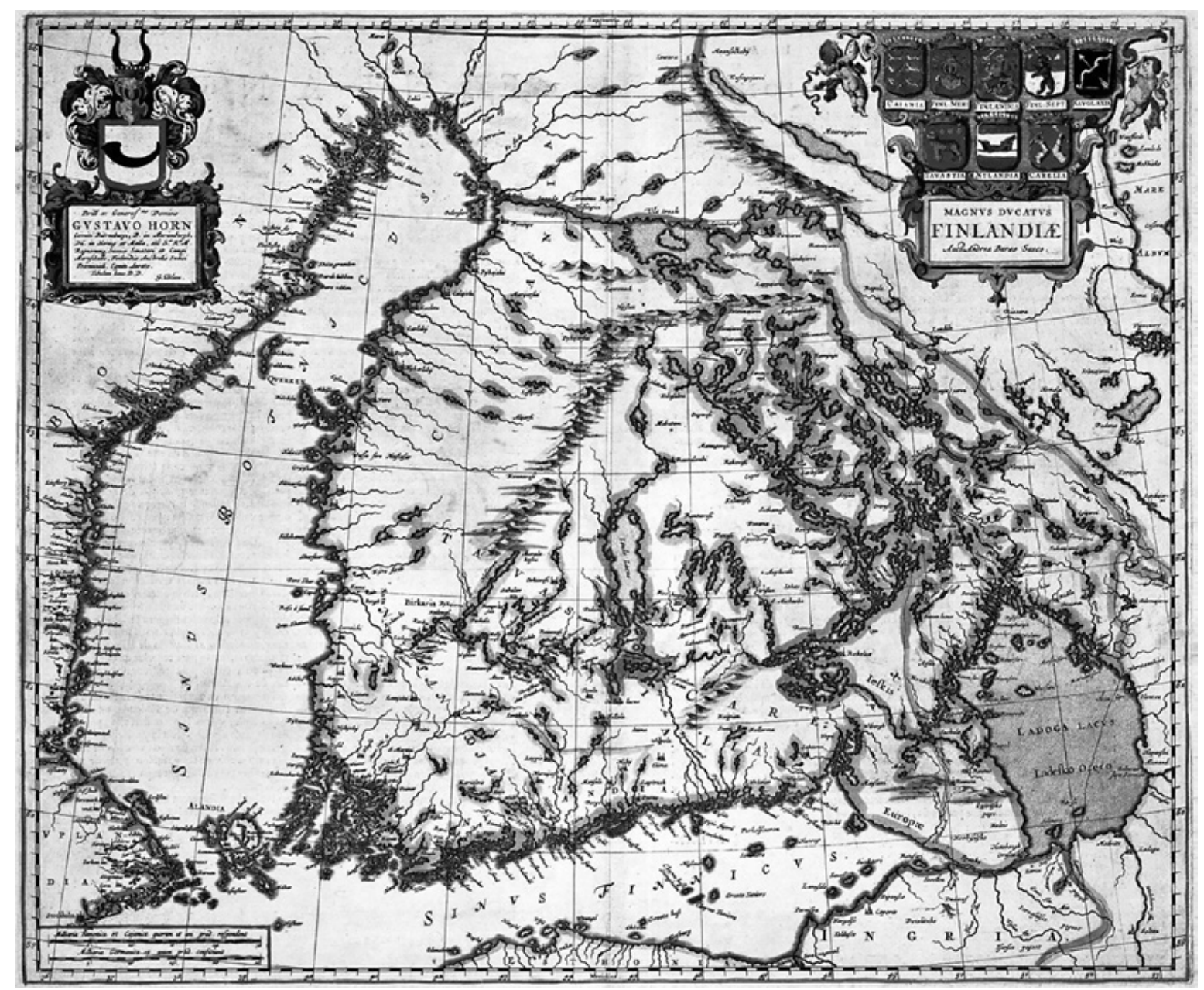

Alankomaalaisen Joan Blaeun (1596-1643) piirtämässä, vuonna 1662 julkaistussa Suomen suuriruhtinaskunnan kartassa näkyy Stolbovan rauhan (1617) raja, joka kulki kaukana Viipurista.

ja Riian kanssa. Valtakunnan Suomen puoleisen osan merkittävin kaupunki Turku oli tässä suhteessa kaukana Viipurin takana. ${ }^{32}$

Viipurin kehitykselle oli tärkeää, että ympäröivän maaseudun asukkaat tulivat tuotteineen vapaaehtoisesti ja hyvillä mielin kaupunkiin. Privilegioidensa ja viimeistään 1500-luvun jälkipuoliskolta vahvan porvaristonsa ansiosta Viipuri oli hyvässä asemassa suhteessa muihin kilpailijoihin. Maalaistenhan ei olisi periaatteessa tarvinnut käydä kaupungissa kuin maksamassa veronsa ja ostamassa säilöntäaineena välttämätöntä suolaa, mutta toki heillä oli muitakin syitä matkata kaupunkiin. Syistä vähäisimpiä eivät liene olleet erilaiset nautintoaineet. ${ }^{33}$ Talonpoikien Viipurin käyntejä lisäsivät aikakauden kuluessa edelleen tiukentuneet kiellot harjoittaa maaseudulla kauppaa (maakauppa) muualla kuin harvoin järjestettävillä markkinoilla. Valtiovallan ohjauksessa Viipurista 
kehittyikin 1500- ja 1600-luvun kuluessa koko Ruotsin valtakunnan itäisen osan hallitseva talouskeskus, jonka sinänsä vähälukuinen porvaristo keräsi maaseudun tuotteet itselleen ja edelleen koti- ja ulkomaankauppaan välitettäväksi.

Onnistuneen strategian tärkeä taustatekijä oli majamieslaitos eli järjestelmä, jossa porvari majoitti kaupungissa vierailulla olleen talonpojan luokseen. Majamies puolestaan sai talonpojasta luotettavan tavarantoimittajan, sillä yösijan lisäksi porvari saattoi antaa talonpojalle luottoa rahaverojen maksuun tai maksaa suoraan tämän verot valtiolle. Järjestelmä hyödytti molempia osapuolia ja oli erityisen käyttökelpoinen Ruotsin itäosien ja Venäjän länsirajan heikosti kehittyneissä taloudellisissa oloissa. Siitä huolimatta Ruotsin kruunu yritti varsinkin 160o-luvulla kitkeä järjestelmää kovin ottein, mutta tulokset jäivät heikoiksi, koska käytäntö oli ajan oloissa toimivin mahdollinen. Ruotsin valtiovalta vieroi majamiehisyyttä ennen muuta siksi, että sen ajateltiin siirtävän maaseudun tuotteet laillisten markkinoiden ulkopuolelle (tiskin alle), mitä pidettiin haitallisena kuninkaalliselle majesteetille, köyhille porvareille ja talonpojille itselleenkin. Järjestelmän sanottiin sitovan talonpojat tiukasti kiinni rikkaisiin porvareihin. Vaikka talonpoikien velkaantumisesta porvareille onkin runsaasti näyttöä, talonpojat eivät tiettävästi koskaan ryhmänä valittaneet majamieslaitoksen ongelmista.

Hyödyt olivat haittoja suuremmat. Maaseudun ostovoima perustui osin siihen, että porvarit lainoittivat talonpoikien hankintoja. Lainananto olisi puolestaan ollut mahdotonta, mikäli porvareilla ei olisi ollut omia pääomia ja luottamusta talollisten kykyyn maksaa velkansa takaisin. Talonpojalle saattoi olla edullista, että kauppias maksoi hänen veronsa suoraan. Porvareiden toiminta ei tältä osin suinkaan ollut pyyteetöntä, mutta ei rosvoustakaan. Valtiovallan esittämistä argumenteista vakavammin otettava oli, että kruunu menetti tullituloja, kun porvari pystyi majamieslaitoksen varjolla siirtämään osan kaupastaan maaseudulle, jolloin valtiolta jäivät saamatta kaupungin portilla perityt pikkutullitulot. ${ }^{34}$

Seuraava esimerkki kertoo eloisasti viipurilaisesta kauppamentaliteetista, vaikka se onkin peräisin vasta Ruotsin ajan jälkeiseltä ajalta. Pormestari Erich Åkerman kirjoitti vuonna 1723 siitä, miten maalaiset saatiin houkuteltua kaupunkiin ja tuomaan tuotteet tutulle kauppiaalle. Åkermanin mukaan maamiehen annettiin "levätä ja virkistyä, jolloin hänen tuliaisikseen tarjottiin viinaa, olutta ja tupakkaa. Muutenkin häntä pidettiin hyvänä ja hän sai vapaasti istua kauppiaan pöydän ääressä niitä (tarjoomuksia) nauttimassa ja häntä puhuteltiin ystävällisesti. Ilman mitään pakotusta hänen kanssaan sovittiin tavarain hinnasta." Myyjä "sai velaksi rahaa tahi tavaraa kuten suolaa, tupakkaa y. m. Jos kauppa oli suurempi, niin maalaiselle lahjotettiin myssy tahi 
hattu taikka muutakin. Erojaisiksi tarjottiin vielä olutta, ruokaa ja tupakkaa. [- - ] Porvariston luona talonpoika sai vapautta, hoitoa, lahjoja ja lainaakin, kuten tavallista oli". ${ }^{35}$

Pormestari Åkermanin kuvaus on silti kaunisteltu, sillä tosiasiassa Viipurin hegemoninen asema Ruotsin valtakunnan itärajalla tarkoitti sitä, että harvalukuisilla kaupungin kauppiailla oli valtaa sanella tuotteiden hinnat. Tässä mielessä talonpojat olivat heikommassa neuvotteluasemassa kuin Länsi-Suomessa tai erityisesti Pohjanmaalla, jossa lähekkäin sijainneiden pikkukaupunkien kilpailu tervasta piti tuotteesta maksetun hintatason pitkään kohtuullisena. ${ }^{36}$ Vastaavaa kilpailutilannetta ei Viipurin seudulla ollut, sillä kaikki Itä-Suomeen ja Suomenlahdelle 1640- ja 1650-luvulla perustetut kaupungit oli tiukasti sidottu Viipurin vaikutuspiiriin. Ennen muuta Lappeenranta, Savonlinna, Kuopio ja Vehkalahti (Hamina) olivat viipurilaisten takamaiden kauppakeskittymiä, eivät varsinaisesti itsenäisiä kaupunkeja. Vehkalahtea lukuun ottamatta kaikki menettivätkin 160o-luvun kuluessa kaupunkioikeutensa. ${ }^{37}$

\section{VÄKILUKU, VERKOSTOT JA AIVOTUONTI}

Viipuri ei ollut valtakunnallisesta merkittävyydestään huolimatta suuri kaupunki. Väkilukuarviot vaihtelevat huomattavasti eri aikoina. 150o-luvulla kaupungissa asui korkeintaan 1500 asukasta, joista vain reilut kymmenen prosenttia oli porvarisvalan tehneitä kauppiaita tai käsityöläisiä. ${ }^{38}$

160o-luvulla kaupungin todellista väkilukua on vaikea selvittää, koska tavallisimmin asukasluvun määrittämisessä käytetty lähdeaineisto eli henkikirjat kertoo yleensä vain verotettujen henkilöiden lukumäärän. Viipuri kärsi 160o-luvulla - kuten jo aiemminkin - toistuvista tulipaloista, joiden seurauksena porvariston ja muiden kaupungissa asuneiden veronmaksukyky aleni, vaikka onnettomuuksista kärsineet eivät jättäneetkään kotikaupunkiaan. Kaupungissa ei suurvalta-ajalla liene koskaan asunut enempää kuin 500 asukasta; toisinaan jäätiin noin puoleen tästä määrästä. Kaupunki oli silti Suomen toiseksi suurin Turun jälkeen ja valtakunnallisesti kymmenen suurimman joukossa. ${ }^{39}$

Kaupunkiväestö oli varhaismodernina aikana värikästä joukkoa, sillä suurin osa asukkaista oli vailla täysiä vaikuttamismahdollisuuksia yhteisössään. Kaikissa kaupungeissa eleli iso joukko sotilaita ja laivamiehiä perheineen sekä monenlaisia suojelusmiehiksi kutsuttuja ryhmiä, samoin kuin palvelusväkeä. Vain porvarisvalan antaneilla porvariston jäsenillä eli kauppiailla ja käsityöläisillä oli kaupungeille suodun itsehallinnon puitteissa täydet toimivaltuudet, kunhan valtakunnallisia lakeja ja asetuksia vain noudatettiin. Hyvän kuvan Viipurin tilanteesta antanee se tosiasia, että merkittäviä kauppiaita ei tarkas- 
telujaksolla tavallisesti ollut kerrallaan yli 40:ää. Käsityöläisiä oli enemmän, mutta käytännössä taloudellisen toiminnan painopiste ja vaikutusvalta oli keskittynyt muutamien harvojen kauppiaiden ja heidän sukulaistensa haltuun. ${ }^{40}$

Eliitin harvalukuisuudesta huolimatta - tai osin ehkäpä osin juuri sen ansiosta - Viipuri oli 1500-luvun jälkipuoliskolta lähtien varsin vetovoimainen ja eloisa kaupunki. Kiinnostavan erityispiirteen kaupunkiin toivat lukuisat liike-elämään vahvasti osallistuneet naiset, joista mainittakoon huomattavina taloudellisina toimijoina esimerkiksi Catharina Hansdotter Cröell, Agneta Rosenbröijer sekä Catharina Walleriansdotter. ${ }^{41}$ Käytännössä kaikissa Ruotsin valtakunnan kaupungeissa kauppiasperheet olivat perheyrityksiä, jossa vaimolla oli vaikutusvaltaa ja vastuuta myös "miehisestä" elinkeinonharjoituksesta, mutta erityisesti lesket pystyivät aikakauden patriarkaalisessa yhteiskunnassakin toimimaan muutoin miehiseen elämänpiiriin kuuluneissa tehtävissä.

Viipuri hyötyi suuresti suhteistaan Itämeren etelärannalle, sillä kaupunki sai runsaasti aktiivisia toimijoita saksankielisestä maailmasta. Varsinkin suurvaltakaudella Viipuri oli valtakunnallisesti merkittävä aivotuonnin kohdekaupunki, vaikka pääkaupunki Tukholma ja 160o-luvulla voimakkaasti kehittynyt Göteborg saivat vielä sitäkin suuremman osan ulkomaalaisinvaasiosta. ${ }^{42}$

Keskiajan lopulla eli 1400-1500-luvun taitteessa Viipurissa asui runsaasti saksalaisia, mutta huomattava osa erityisesti Venäjän (Novgorodin) ja lännen markkinoiden välittäjistä jätti 1520-luvun loppuun mennessä kaupungin ja koko valtakunnan. Kalmarin unionin romahtamisesta ja Kustaa Vaasan tiukoista toimista seurannut saksalaiskauppiaiden poismuutto heikensi Viipurin merkityksen murto-osaan entisestä jopa vuosikymmeniksi. J. W. Ruuth katsoikin, että 1500-luvulla viipurilaisilta puuttui niin pääomaa, osaamista kuin potentiaalisten liikekumppanien luottamuskin. Erityisen kiinnostavaa tässä tilanteessa onkin se, kuinka korostetun esivaltavetoista uusien taloudellisten toimijoiden rekrytointi Vaasa-kauden alussa oli. Toisin sanoen kruunun edustajat hankkivat aktiivisesti vetreitä tulokkaita, ja rekrytoijista omaa luokkaansa oli Kustaa Vaasan itärajan luottomies Klaus Kristerinpoika Horn, joka värväsi 1500-luvun puolimaissa Saksasta puolisen tusinaa kokenutta kauppiasta opettamaan viipurilaisia kaupanteossa. Nämä miehet - erityisesti Hans Lakman, Jakob Grothusen, Donatus Deutschman, Per Vintapper, Vit Olde ja Klaus Makeprang - saivat palkkiokseen erityisvapauksia muun muassa tullimaksuista. ${ }^{43}$

Aikakauden erikoista ilmapiiriä kuvastaa, että hallitsijat pitivät "kosmeettista meteliä" ulkomaalaisia vastaan, vaikka viipurilainenkin esimerkki osoittaa, kuinka välttämätöntä maahan oli saada kansainvälisen tason asiantuntijoita eri aloilta. Siksi tietonsa, taitonsa, yhteytensä ja pääomansa mukanaan tuoneet vierasmaalaiset saivat esivallan kovista sanoista huolimatta toimia suhteellisen 
löyhässä lieassa myös 160o-luvun Viipurissa. ${ }^{44}$

Saksalaisten tulokkaiden opit kantoivat pian hedelmää, sillä jo 1500-luvun lopulla viipurilaiset olivat saaneet kokemusta sekä kansainvälisestä kaupasta että luotettavan maineen liikekumppaniensa keskuudessa. Viipurin taloudellinen nousu puolestaan merkitsi sitä, että kaupunki alkoi näyttäytyä houkuttelevana uusille tulokkaille. J. W. Ruuth kirjoitti "muukalaisten valtavasta virrasta" erityisesti 1630- ja 1640-luvulla. Tällä kertaa Viipuriin haluttiin tulla omaehtoisesti, kun taas muualla valtakunnassa valtio hoiti houkuttelun ja rekrytoinnin. Muuttoliike kaupunkiin vaimeni vasta 166o-luvulla eli se jatkui Viipuriin noin vuosikymmenen kauemmin kuin muihin valtakunnan kaupunkeihin. ${ }^{45}$

Tätä taustaa vasten on mielenkiintoista, kuinka paljon 160o-luvun Viipurissa valitettiin kaupungin hallinnossa ja taloudessa havaituista sukulaisverkostoista sekä erilaisten sukulaissuhteiden aiheuttamista jääviys- tai paremminkin jääväämättömyysongelmista: suuri osa valtaapitävistä oli aikalaiskäsitystenkin mukaan vähintään langoksia keskenään. Taloudellisesti vilkkaan Viipurin eliitit olivat kapeita, ja esimerkiksi raastuvanoikeuden jäsenten täytyi olla hyvin perillä kaupallisista asioista, jotta oikeudenkäyttö olisi ollut asiantuntevaa, oikeudenmukaista ja tehokasta. ${ }^{46}$ Monet uusistakin tulokkaista pääsivät mukaan hallintoon ja taloudellisen vaikutusvallan sisäpiireihin: usein se toteutettiin mahtisukujen keskinäisin naimakaupoin, ja hyvän pelisilmän omanneet laivan tuomat pääsivät samalla tavalla mukaan viipurilaiseen todellisuuteen. ${ }^{47}$

Viipuri oli 1500- ja 1600-luvulla monikulttuurinen ja -kielinen kaupunki. Aiemmassa tätä aikakautta koskevassa tutkimuksessa on korostettu eri kieliryhmien välisiä kiistoja, mutta tulkintoihin lienevät vaikuttaneet 1900-luvun alun vaikea venäläistämiskauden ilmapiiri sekä lähdeaineistoissa väistämättä korostuvat konfliktit, sillä monia riitoja käsiteltiin oikeusistuimissa. Kielitieteilijöille monikieliset yhteisöt näyttäytyvät ennen muuta kielikontakteina, kielikilpailuna ja kielikonflikteina, joita kaikkia tavataan myös varhaismodernin ajan Viipurista. ${ }^{48}$

Tärkeitä porvarissukuja olivat 160o-luvulla esimerkiksi Tesche, Boisman, Schemedeman, Barckhusen, Winter ja Sutthoff, joista monet olivat merkittäviä Ruotsin ajan jälkeenkin. ${ }^{49}$ Vaikka tulokassuvut usein "ruotsalaistuivat" nopeasti, kaupungin eliittiin kuului suurvaltakaudella myös paljon saksankielisiä toimijoita. Marika Tandefelt ja Robert Schweitzer ovat korostaneet saksalaisten tulokkaiden tietopääomaa ${ }^{50}$ sekä sitä, että varsinkin hallinnossa mukana olevien tuli taitaa valtakunnan virallista kieltä ruotsia. Tilanne muuttui vuoden 1710 jälkeen, jolloin saksasta tuli noin vuosisadaksi hallinnon kieli.

Kaupan ja käsityönharjoittajien oli hallittava ainakin jossain määrin myös talonpoikien kanssa käytettävää suomea. Kaupungin asukkaista suuri osa oli 
koko ajan suomenkielisiä, mutta vahvoja taloudellisia tai poliittisia toimijoita heidän joukossaan oli vähän. Aikakauden kuluessa Viipurissa, kuten muissakin Suomen puoleisen valtakunnan kaupungeissa, suomenkielisten porvareiden merkitys väheni entisestään. Jos vielä 1550- ja 1560-luvun vaihteessa kymmenen eniten veroa maksavan kaupunkilaisen joukossa oli melkein puolet suomenkielisiksi ${ }^{51}$ tulkittavia henkilöitä, jo puoli vuosisataa myöhemmin tilanne oli muuttunut täysin. Tämäkin kertoo kaupungin vetovoiman kasvusta ja uusien varakkaiden tulokkaiden saapumisesta. Venäläisistä puhutaan tällä jaksolla harvinaisen vähän, vaikka toki he esiintyvät usein oikeusistuimissa erilaisissa velka-asioissa: varsinkaan 1500-luvun virallisissa asiakirjoissa hallitsijan kielenkäyttö ei tältä osin ole kovinkaan diplomaattista. ${ }^{52}$

Esimerkiksi värikäs ja riitaisa kauppias, pormestariksi ja myöhemmin aateliseksi ylennyt Johan Cröell osasi todistettavasti suomea. Pormestari kehuskelikin kielitaidollaan, joka tosin konkreettisimmillaan näkyi rehevänä suomenkielisenä kiroiluna. ${ }^{53}$ Juuri tällaisissa yhteyksissä monikielisyys tulee aikalaislähteistä väkevimmin esille, kuten esimerkiksi vuonna 1648, jolloin suomenkielinen kaupungin laivamies kutsuttiin todistamaan kaupungin pormestari Hans Schmedemanin ja kruunun virkamiehen, kamariviskaali Samuel Cröellin (Johan Cröellin veli) välisessä voimakassanaisessa riita-asiassa. Tuomarit halusivat varmistua todistajan kelpoisuudesta lausunnonantajaksi, minkä vuoksi he kysyivät, ymmärsikö laivamies varmasti ruotsia ja saksaa. Todistaja kertoi ymmärtävänsä "tarkasti" (nogsamt), kun joku kiroili - mikä sekin oli aikakaudella vakavaksi rikkeeksi katsottua jumalanpilkkaa - ja sellaisesta puheesta oli ollut kyse. ${ }^{54}$

\section{RAKENNETUN YMPÄRISTÖN JA AIKAKÄSITYSTEN MUUTOKSET}

Rakennettu ympäristö ja topografia ovat olleet tärkeitä Viipuri-tutkimuksen teemoja jo pitkään. Traditiota loivat tältä osin etenkin Gabriel Lagus sekä kaupungista fyysisenä ympäristönä laajasti kirjoittanut J. W. Ruuth, joiden näkökulmavalintoihin vaikuttivat teosten laatimisaikana 1800- ja 1900-luvun vaihteessa edelleen olemassa olleet rakennukset ja artefaktit, samoin kuin monipuolinen aikalaislähdeaineisto. Keskiaikainen asemakaava on kiehtonut monia, mutta vielä enemmän on tutkittu 1630-luvun lopulta laadittuja uudistussuunnitelmia, joissa keskiaikaisia katuja purettiin osin häikäilemättömästi uuden regulariteetin [eli rakennuskaavan] tieltä. Uusin tutkimus korostaa, kuinka Viipurin vuoden 1649 ruutukaavasuunnitelma tavoitteli käytännön sovellutusta. Taidehistorioitsija Nils Ahlberg pitää mainittua Viipurin suunnitelmaa lähes yhtä monimutkaisena kuin Tukholman ja Riian samoihin aikoihin laadittuja. Saavutus on merkittävä, sillä pääkaupungissa tapahtui suur- 


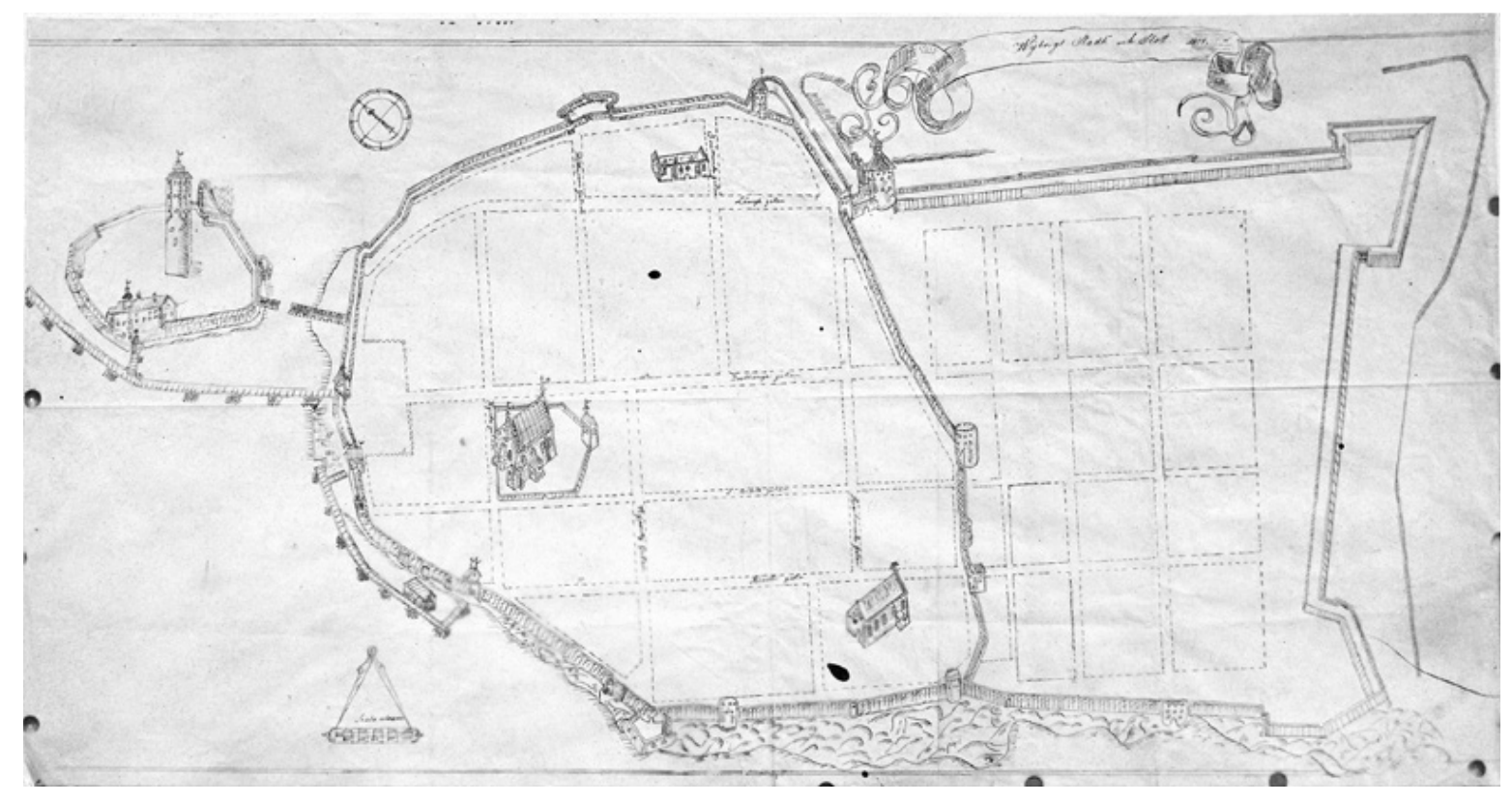

Viipuriin uusittuun asemakaavaan vuodelta 1642 on kuvattu myös kaupungin merkittävimmät kirkot. Linnaan on piirretty vain Pyhän Olavin torni ilman ympäröiviä rakennuksia.

valta-ajalla erityisen paljon tälläkin elämänalueella ja Riika oli koko Ruotsin valtakunnan ylivoimaisesti suurin kaupunki. ${ }^{55}$

Viipurin rakennetun ympäristön erityisyys muodostui jo keskiajalla linnan läheisyydestä ja itse kaupungin linnoittamisesta. Kaupunginmuuri oli tullut valmiiksi 1470-luvulla. Missään vaiheessa Viipuria ei kuitenkaan voi pitää kivestä rakennettuna kaupunkina, vaikka valtiovalta alkoi eri keinoin tukea kivitalorakentamista 1540 -luvulta. ${ }^{56}$ Ensimmäisen kerran Kustaa Vaasa suostui 1541 kaupunkilaisten pyyntöön vahvistaa kaupunginmuuria ja tornia uskonpuhdistuksessa merkityksensä menettäneiden kahden luostarin tiilillä. ${ }^{57}$ Viipurin linnoittamiseen myönnettiin myös esimerkiksi 1547 maanapu (landz hielp) -niminen vero kaikkialta Suomesta. Vuonna 1555 viimein valmistunut Pyöreä torni oli konkreettisin osoitus varustamisesta, johon käytettiin suuri määrä talonpoikien veropäivätöitä. ${ }^{58}$

Kustaa Vaasa antoi useaan otteeseen kaupunkilaisille määräaikaisia verovapauksia ja luovutti kuninkaan osuuksia veroista ja sakkotuloista takaisin kaupungille sillä ehdolla, että säästyneet varat käytettäisiin kaupungin ulkoasun kohentamiseen. ${ }^{59}$ Kustaa Vaasa patisteli kaupunkilaisia linnoittamaan kotikaupunkiaan ja hänen seuraajansa velvoitti linnanpäällikön valvomaan työtä. ${ }^{60} 1560$-luvulta hallitsijoiden retoriikkaan ilmestyy ankaria sanamuotoja, joissa kuninkaan luottomiehet määrättiin repimään kaupungista puurakennuksia, varsinkin kaupunginmuurin lähistöltä. ${ }^{61}$ 
Kaupunkilaisia puolestaan kannustettiin purkamaan puutalot yleisten tulipalojen vuoksi: yhteensä vuosina 1575-169o Viipurissa koettiin vähintään 11 vakavaa tulipaloa, jotka heikensivät kaupungin elinvoimaa. Raskaita tuhoja koitui esimerkiksi vuonna 1575, jolloin menetettiin muun muassa raatihuone ja kirkko. Vuonna 1594 kaupunki paloi aikalaisarvioiden mukaan täydellisesti, minkä vuoksi Viipuri sai valtakunnan kriittisestä taloustilanteesta huolimatta vuoden täydellisen verovapauden. Vuoden 1652 palossa tuhoutui puolestaan 300 taloa ja 1690 kaksi koulua ja 60 taloa. ${ }^{62}$

Kehotukset, määräykset ja maanittelu eivät tuottaneet hyviä tuloksia. Jokseenkin yhtä tehotonta oli hallitsijoiden kivitalojen rakentajille lupaamat verohelpotukset. Ensimmäisen kerran tukipalkkioita luvattiin vuonna 1569, kun kivitalon rakentajille myönnettiin kymmenen vuoden verovapaus kruununveroista - jos talo valmistui tuon ajan kuluessa, lisäetu oli kaksi lisävapaavuotta ${ }^{63}$ Seuraavana vuonna alkanut ankara sotakausi vaikutti sekä käytännön mahdollisuuksiin että sanamuotoihin. Niinpä hallitsija määräsi 1583 Käkisalmen käskynhaltijana toimineen luottomiehensä Henrik Klassonin (Horn) kehottamaan painokkaasti viipurilaisia rakentamaan kivitaloja "tai ainakin kattamaan puutalonsa" - sanamuodossa näkyy tappion ja realismin maku. ${ }^{64}$ Vuosien 1612 ja 1613 tulipalojen jälkeen Kustaa II Aadolf lupasi jälleen verohelpotuksia kivitalon rakentajille. ${ }^{65}$ Vastaava määräys toistettiin vuoden 1628 suurpalon jälkeen, kun kaupungin "suurin ja parhain osa" raatihuone mukaan luettuna tuhoutui. ${ }^{66}$ Toisin sanoen tavoite Viipurin muuttamiseksi kivikaupungiksi ei onnistunut, vaikka yrityksen puutteesta ei valtiovaltaa eikä kaupunkilaisiaan voi syyttää. J. W. Ruuth mainitsee, että vuoteen 1611 mennessä tukien avulla rakennettiin pari kivitaloa. ${ }^{67}$

Kaupungin itsehallinnon symboli raatihuone tuhoutui tarkastelujaksolla pariinkin otteeseen. Raatihuone oli kaikkialla kaupungin symboli ja siinä suhteessa Viipurin raastuvanoikeuden evakkokaudet eivät tehneet hyvää kaupungin ja sen johtajien legitimiteetille ja yleiselle uskottavuudelle. Vuoden 1628 jälkeen kaupungissa ryhdyttiin ensimmäisen kerran suunnittelemaan kivisen raatihuoneen rakentamista, johon työhön päästiin lopulta vasta 1640-luvulla. Raastuvanoikeus pääsi uusiin tiloihinsa viimein vuonna 1658, mutta lopullisesti Suomen puoleisen valtakunnan ainoa kaksikerroksinen raatihuonerakennus valmistui vasta kaksi vuosikymmentä myöhemmin. ${ }^{68}$

Viipurin kaupunki ja sen asukkaat olivat osa prosessia, jossa 1500- ja 160o-luvun ihmisten syklinen aikakäsitys muuntui entistä lineaarisemmaksi. Ajan kurinalaistumisen ja pitkäjänteisen suunnittelun korostumisen taustalla oli useita tekijöitä, joista tärkeä oli nimenomaan valtiovallan vaatimus tehtävien nopeasta ja ennustettavasta hoitamisesta. Ajan kurinalaistuminen on yhdistetty myös sivilisaatioprosessiin, jonka keskiössä kaupungit talouden ja henkisen 
elämän keskuksina olivat. Aikaa mittaavat kellot muodostuivat tässä tilanteessa tärkeäksi apuvälineeksi: vain harvalla varakkaallakaan porvarilla oli henkilökohtaisia kelloja, sen sijaan viimeistään 160o-luvun kuluessa kaikkiin Ruotsin valtakunnan kaupunkien julkisiin tiloihin hankittiin ajannäyttäjiä - tuntikelloja eli seijareita. Yleensä ne sijoitettiin joko kirkon tapuliin tai raatihuoneelle. Näin oli myös Viipurissa, jossa oli jo pitkään ollut kaksi kelloa, yksi kirkon kellotapulissa ja toinen linnassa. Tosin vuonna 1619 ne olivat molemmat toimintakyvyttömiä, minkä vuoksi kelloseppä Lorenz sai tehtäväkseen rakentaa linnaan uuden kellon. Sama käsityöläinen sai sittemmin vuonna 1642 tilauksen Turusta, kun turkulaiset pyysivät häneltä kellon raatihuoneelleen. ${ }^{69}$

Viipurilaiset ja muut merkittävien kaupunkien asukkaat olivat tässäkin mielessä aikakäsityksen kurinalaistamisessa eturintamassa. Valtiovaltaa asia kiinnosti jo varhain. Niinpä vuoden 1619 tärkeä kaupunkihallintosääntö määräsi kaupunginkirjurin merkitsemään tarkasti muistiin kaikki asioiden käsittelyssä oleelliset kellonajat. ${ }^{70}$ Hallinnollisen päätöksenteon jämäköitymisen ohella täsmentyi myös oikeudenkäyttö, sillä ajan merkitystä korosti myös Viipurin oikeuslaitokselle vuonna 1634 annettu ohjeistus. Kaupungin raati puolestaan istui yleensä aamuisin parin tunnin ajan ja tuomareiden oli saavuttava oikeuteen viimeistään raadin kellon soitua. Jo 160o-luvun puolivälistä on olemassa tietoja, joiden mukaan valtaapitävillä porvareilla oli henkilökohtaisiakin kelloja. ${ }^{71}$

\section{RAUHALLINEN, MUTTA KOVAÄÄNINEN JA -KIELINEN KAUPUNKI}

Viipuri oli 1500- ja 1600-luvulla poikkeuksellisen rauhallinen kaupunki, ainakin jos asiaa tarkastelee oikeuslaitoksen aineistoista. Silti kaupungin menneisyyttä käsittelevissä kirjoituksissa korostetaan usein erilaisia eliitin jäsenten välisiä konflikteja. Tällainen käsitys pitää suurelta osin paikkansa, sillä harvalukuinen eliitti kärhämöi ja tappeli keskenään. Viipurille tyypillisesti tapaukset olivat yleensä saaneet alkunsa taloudellisista kiistoista ja usein sukulaisuussuhteessa. 160o-luvun tuomiokirja-aineistoa on Viipuri-tutkimuksessa käytetty lähinnä havainnollistamaan aikakauden elämäntapojen raakuutta, vaikka tosiasiassa oikeudenkäyntimateriaali tarjoaa parhaat mahdollisuudet myös henkisen kulttuurin tarkasteluun. ${ }^{22}$

Taulukko 1 (sivulla 38) osoittaa, että suurvaltakauden alkupuolen Viipurin kaupunkituomioistuimissa annettiin runsaasti langettavia tuomioita erilaisista talousrikoksista; peräti neljännes kaikista tapauksista koski kauppalainsäädännön rikkomuksia. Tällaisten juttujen suhteellisen korkea osuus heijastelee paitsi Viipurin talouselämän vilkkautta, myös taloudellisten rikkomusten tiukkaa valvontaa viimeistään 1640-luvun lopulta lähtien. Tältä osin Viipuri 


\begin{tabular}{|l|c|c|}
\hline & lukumäärä & \% \\
\hline talous & 415 & 26 \\
\hline kunnia & 288 & 18 \\
\hline väkivalta & 367 & 23 \\
\hline siveellisyys & 128 & 8 \\
\hline varkaus & 80 & 5 \\
\hline tottelemattomuus & 112 & 7 \\
\hline muut & 208 & 13 \\
\hline yhteensä & 1598 & 100 \\
\hline
\end{tabular}

Taulukko 1. Viipurin rikosrakenne 16221660. Lähde: Viipurin raastuvan- ja kämnerinoikeuden tuomiokirjat; Karonen 2010. poikkesi muista varhaismodernin Ruotsin kaupungeista. Sen sijaan väkivaltarikosten ja kunnianloukkausten korkeat osuudet eivät olleet ominaisia pelkästään Viipurille, vaan kaikille aikakauden pohjoiseurooppalaisille kaupunkiyhteisöille. Tosiasiassa Viipuri oli yksi Suomen puoleisen valtakunnan rauhallisimmista kaupungeista, sillä siellä tehtiin 1500-160o-luvuilla sekä absoluuttisesti että väkilukuun suhteutettuna paljon vähemmän henkirikoksia kuin suomalaisissa kaupungeissa keskimäärin. ${ }^{73}$

Sen sijaan kaupungissa pidettiin usein kovaa ääntä. Pilkan ja epäkunnioituksen kohteeksi joutuivat ennen muuta kaupungin johtomiehet, mutta eipä heidän oma käytöksensäkään aina ollut tehtävän edellyttävän arvokkaan käytöksen tasalla, kuten Johan Cröellin esimerkki edellä osoitti.

Vaikka aikakauden kulttuuri oli pääasiassa suullista, Viipurin erityislaatuinen tuomiokirja-aineisto tarjoaa edellytykset myös kirjallisen kulttuurin tarkasteluun, sillä oikeuden pöytäkirjat ovat pullollaan hyvin tiheästi kirjattuja todistuksia erilaisista yhteisöllisistä sattumuksista. Tästä syystä aiempi tutkimus on kiinnittänyt erityistä huomiota eliittien keskinäisiin riitoihin, vaikkei niitä erityisen runsaasti esiintynytkään. Kuitenkin monen oikeustapauksen osallisina olivat raadin jäsenet tai myöhemmän elämänsä varrella merkittäviin asemiin nousseet hallintomiehet. Julkinen kärhämöinti ei tietenkään ollut omiaan rakentamaan ja ylläpitämään raadin ja eliittien auktoriteettia. ${ }^{74}$ Niiden maineen kannalta ongelmallisia olivat myös monet 160o-luvun alkupuolella kiusallisen usein toistuneet tapaukset, joissa raadin jäsenet ja yhteisönsä varakkaimmat kauppiaat olivat laiminlyöneet kenties tärkeimmän tehtävänsä, kotitaloutensa isännän eli patriarkan vastuun. Monet heistä eivät näet olleet valvoneet riittävästi palvelusväkensä siveellisyyttä, josta puhdasoppisuuden ajalla pyrittiin ainakin lainsäädännön ja ihanteiden tasolla pitämään tiukasti kiinni. ${ }^{75}$

Viipurissa tavataan Turun tapaan aivan erityisiä häväistyskirjoitusten tekijöitä. Turussa tekstejä kynäilivät usein uhmakkaat ylioppilaat ennen muuta omista professoreistaan ja vain harvemmin kaupungin mahtimiehistä. Viipurissa kirjoitusten kärki oli suunnattu nimenomaan kaupungin johtaviin porvareihin ja hallintomiehiin ja sulkakynän varressa oli vähintään puoliammattilaisia. ${ }^{76}$ Nämä yleiseurooppalaiset häväistyskirjoitukset eli paskillit (pasquiller) kertovat omalla valtaapitäville piinallisella tavallaan paikallisesta kult- 
tuurista, vaikka toki kirjalliset esitykset olivat kärjistettyjä ja pahimmillaan mitä törkeintä panettelua. Tekstit olivat järjestelmälle erityisen vaarallisia silloin, kun niissä pilkattiin avoimesti raatiherroja ja porvareita. Kaikkein kuuluisimmat pilkkakirjoitukset olivat 1670 -luvun alussa viipurilaisen, omat liiketoimensa pahasti sotkeneen kirjanpitäjä Paul Moijin käsialaa. Hänen alun perin saksaksi laatimansa ja myöhemmin ruotsiksi käännetyt kirjoituksensa levisivät laajasti kaupungilla ja erilaisissa ravitsemusliikkeissä. Moijin mukaan yksi pormestari ei ymmärtänyt laista juuri mitään; toisella oli iso pää kuin hevosella, mutta ei yhtään järkeä. Kolmas oli iän myötä muuttunut uudelleen lapseksi. Kirjoitus kyseenalaisti myös raatimiesten laadun: heissä oli vikoja tyhmyydestä juoppouteen ja huikentelevaisuuteen saakka. Se, että kaikille hahmoille löytyi helposti vastine todellisuudesta, ei luonnollisesti ainakaan lievittänyt raatiherrojen tuskaa. ${ }^{77}$

\section{KOULUT, KIRJAT JA KUVATAITEET}

Viipurissa koulutus keskittyi useimpia muita Suomen kaupunkeja enemmän reaaliaineisiin sekä käytännölliseen ja suoraan talouselämän tarpeita palvelevaan opetukseen. Viipurilaiset eivät Ruotsin ajalla arvostaneet korkealle kirkon johtamaa ja lähes yksinomaan uskonnollisista tarpeista lähtevää koulutusta. Kaupunkiin oli vuonna 1641 perustettu kaksiluokkainen lukio, mutta sen suosio ei häikäissyt. Niinpä kaupunkiin vuonna 1688 ensimmäisen kirjapainon perustanut Viipurin piispa Petrus Bång totesikin 169o-luvun alussa, kuinka Viipurissa "puotipoika on suurempiarvoinen kuin oppinut mies (litteratus)" - piispan mukaan lukion opettajia ja oppilaita peräti halveksittiin. Sen sijaan kaupunkilaiset rekrytoivat suoraan Saksasta kotiopettajia ja kustansivat porvariston käyttöön viimein 160o-luvun lopulta yksinomaan käytännön aineisiin - saksan kieleen, lukemiseen, kirjoittamiseen ja laskentoon - keskittyneen saksankielisen koulun: sitä voi pitää ammattimaisen koulutuksen ensiasteena. Koulu oli monin tavoin edistyksellinen, sillä poikien joukossa oli oppia saamassa myös muutama tyttö. ${ }^{78}$

Akateeminen sivistys ei todellakaan ollut keskeinen osa viipurilaisten arkea tarkastelujaksolla. Vain harva viipurilainen harjoitti yliopisto-opintoja (taulukko 2, sivulla 40). Ne viipurilaiset, jotka akateemiselle tielle silti lähtivät, tavoittelivat kyllä aikakauden sääty-yhteiskunnan ideaalien mukaisesti säätynousua, mikä näkyy aikanaan valmistuneiden ylioppilaiden huomattavana, noin 40 prosentin osuutena kirkollisissa tehtävissä. Taulukko paljastaa myös sen, että Viipuri kärsi yliopisto-opintojen myötä aivovuodosta, sillä vain noin joka toinen opiskelemaan lähtenyt palasi edes Viipurin hiippakuntaan. ${ }^{79}$ 


\begin{tabular}{|c|c|c|c|c|c|c|c|c|c|c|}
\hline & \multicolumn{7}{|c|}{ Ylioppilaan isän ammatti } & \multirow[b]{2}{*}{ 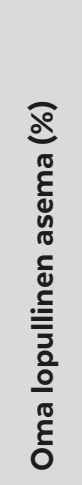 } & \multirow[b]{2}{*}{ 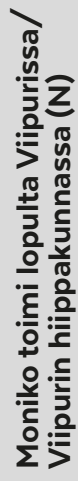 } \\
\hline & & $\begin{array}{l}\frac{1}{\pi} \\
\text { ? } \\
\text { व }\end{array}$ & 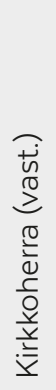 & $\frac{\overline{0}}{\frac{2}{0}}$ & 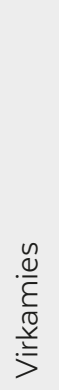 & 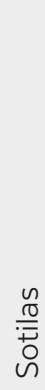 & $\frac{3}{2}$ & 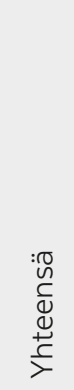 & & \\
\hline \multirow{8}{*}{ 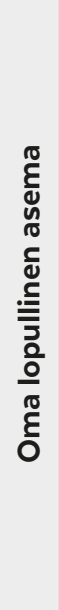 } & Porvari & 7 & 0 & 0 & 0 & 0 & 0 & 7 & 6 & 5 \\
\hline & $\begin{array}{l}\text { Kirkkoherra } \\
\text { (vast.) }\end{array}$ & 22 & 6 & 4 & 3 & $\mathrm{O}$ & 0 & 35 & 30 & 27 \\
\hline & Pappi & 8 & 2 & 2 & 2 & 0 & 0 & 14 & 12 & 12 \\
\hline & Virkamies & 19 & 2 & 1 & 11 & 0 & 0 & 33 & 28 & 7 \\
\hline & Sotilas & 1 & 1 & 1 & 5 & 1 & 0 & 9 & 8 & 0 \\
\hline & Muu & 0 & 0 & 0 & 1 & 0 & 0 & 1 & 1 & 0 \\
\hline & $\begin{array}{l}\text { Ei tietoa/ } \\
\text { kuoli nuorena }\end{array}$ & 13 & 4 & 1 & 1 & 0 & 0 & 19 & 16 & 0 \\
\hline & Yhteensä & 70 & 15 & 9 & 23 & 1 & 0 & 118 & 100 & 51 \\
\hline \multicolumn{2}{|c|}{ Isän asema (\%) } & 59 & 13 & 8 & 19 & 1 & 0 & 100 & - & - \\
\hline
\end{tabular}

Taulukko 2. Viipurilaiset ylioppilaat Turun Akatemiassa, Upsalan yliopistossa ja Tarton yliopistossa sekä heidän sijoittumisensa vuosina 1640-1710. Lähde: Helsingin yliopiston ylioppilasmatrikkeli 1640-1852 (www.helsinki.fi/ylioppilasmatrikkeli).

Tästä huolimatta ja osin sen vuoksi viipurilaisista porvareista on jäljellä jonkin verran erilaisia painotuotteita erityisesti 160o-luvun jälkipuoliskolta. Osan julkaistuista kustansivat kauppiaat ja virkamiehet itse, mutta myös yliopisto-opiskelijat saattoivat laatia ajalle tyypillisiä promootiorunoja kotikaupunkinsa, suosijoidensa ja akateemisia oppiarvoja saavuttaneiden ystäviensä kunniaksi. ${ }^{80}$ Oma lukunsa olivat erilaiset pappissäädyn piirissä laaditut tekstit, joita on säilynyt jo varhemmilta ajoilta. Silti ensimmäisiin aidosti viipurilaisiin pienjulkaisuihin kuuluivat kauppias Hans Schmidtin ja raatimiehen tytär Beata Ruuthin solmiman avioliiton kunniaksi painettu ruotsinkielinen hääruno (1653). Samoihin aikoihin alkoi ilmestyä tasaiseen tahtiin myös merkkihenkilöiden ja mahtisukuihin kuuluneiden ruumissaarnoja.$^{81}$ Toisenlaisesta sanataiteilusta käy esimerkiksi runo, jonka viipurilainen porvarinpoika Olaus Qvast kirjoitti 
niin ikään viipurilaiselle raatimiehen pojalle Henrik Winterille sekä Räisälän kirkkoherran pojalle Gustaf Bernerille sen kunniaksi, että nämä valmistuivat maistereiksi vuonna 1679. Sen säkeet kertoivat, kuinka Karjalan kansa kiitti vihittäviä maistereita siitä, että he olivat osoittaneet, kuinka "Carjalaskin inhimisitä On: ei vaivon muilla mailla”. Hannes Sihvo tulkitsi kirjoituksen protestiksi länsisuomalaisten akateemisten piirien käsitykselle, jonka mukaan Karjala ja Viipurikin olivat alempiarvoisia tai primitiivisiä verrattuna Turunmaahan..$^{82}$

Qvastin runo tiivistää monia tässäkin esityksessä nousseita havaintoja. Viipurilainen kulttuuri ei yleisesti ollut kovin kirjallista tai henkisesti korkeatasoista. ${ }^{83}$ Silti ainakin virkamiesten piirissä tavattiin jo $1600-l u v u n$ puolimaissa monipuolisia kirjastoja, joissa saattoi olla kymmeniä teoksia useilla eri kielillä, tavallisimmin toki ruotsiksi, latinaksi ja saksaksi. Lisäksi ainakin raastuvanoikeuden tuomareilla oli - kuten monissa muissakin kaupungeissa - oikeustieteellistä kirjallisuutta ja lakitekstejä. Erilaiset uskonnolliset julkaisut kuuluivat monien porvarien vakiolukemistoihin. Raastuvanoikeudessa kirjattiin vuonna 1649 poikkeuksellisen tarkasti muistiin kaupungin entisen kuninkaallisen pormestari Casper Thilen ja hänen taloudellisiin vaikeuksiin joutuneen poikansa, Viipurin läänin veromestari Carl Thilen omaisuus. Irtaimistojen ja erilaisten arvoesineiden joukossa olivat myös isän ja pojan kirjastot. Casper Thilellä oli vähintään kolmisenkymmentä nidettä sisältänyt kokoelma, johon kuului tavanomaisten sana- ja lakikirjojen sekä ruotsin- ja saksankielisten uskonnollisten teosten ohella muun muassa nürnbergiläisen oikeustieteen tohtori Jacob Airerin Processus juris, ranskalaisen katolisen juristin, filosofin ja historiantutkija Jean Bodinin Historiae (todennäköisesti teos Methodus ad facilem historiarum cognitionem vuodelta 1566) sekä Vergiliuksen runoja ja Terentiuksen komedioita. Carl Thilellä puolestaan oli vain kymmenisen teosta, joista suurin osa oli hartaus- ja uskonnollista kirjallisuutta, mutta myös veromestarille tarpeellinen teos aritmetiikasta. ${ }^{84}$

Hengentuotteiden lisäksi Thilet omistivat laajan taulukokoelman, sillä Carl oli hankkinut muun muassa yhdeksän kehystettyä muotokuvaa ja Casper Thile piti seinällään "kuninkaallisten majesteettien muotokuvia" sekä maalauksia tuolloin jo entisestä Viipurin läänin maaherra Carl Mörneristä, kansleri Axel Oxenstiernasta ja valtakunnan veromestari Gabriel Bengtsson Oxenstiernasta. Samoin tärkeitä olivat kuvat vaimosta ja muista sukulaisista. ${ }^{85}$ Jos aikakauden mittapuun mukaan ilmeisen korkealla virkapalkallaan ${ }^{86}$ eläneillä miehillä oli hallussaan tällaisia kokoelmia, niin niitä löytyi mitä todennäköisimmin myös terva- ja kotimaankaupalla rikastuneiden kauppiaiden kodeista. Tällaiset esineet olivat mitä suurimmassa määrin statussymboleja, joiden rahallinen arvo sinänsä ei ollut välttämättä korkea tai eliittien edustajille olennainenkaan. 


\section{VIIPURI TALOUSELÄMÄN JA KULTTUURIN KESKUKSENA}

Viipuri oli 1500- ja 1600-luvulla merkittävä taloudellinen keskus, jonka voimakkain kehitysvaihe alkoi 1500-luvun lopulla. Nousu käynnistyi samoihin aikoihin kuin kaupungille ja koko Ruotsin valtakunnalle tärkeä itäraja vähitellen rauhoittui pitkän, rajaseutuja ja kauppayhteyksiä raunioittaneen sotakauden jälkeen.

Jo sotakaudella viipurilaiset olivat pystyneet rakentamaan kulloiseenkin Ruotsin hallitsijaan toimivan keskusteluyhteyden. Argumentaatiotaidot ja kaupungin vähitellen vahvistunut taloudellinen tilanne tarjosivat keinot parantaa kaupungin ja varsinkin sen vähälukuisen eliitin asemaa ja mahtia. Viipurilaisten omaleimaiseen poliittiseen kulttuuriin kuului pitkään suora yhteydenotto maallisen esivallan korkeimpiin edustajiin. Vielä kauan senkin jälkeen, kun Ruotsi oli menettänyt 170o-luvun alussa kaupungin Venäjälle, Ruotsin Suomen puolelle siirtyneet entiset viipurilaiset siinä kuin kotiseuduilleen jääneet kaupunkilaisetkin vetosivat taitavasti ja aggressiivisestikin vanhoihin saavutettuihin etuoikeuksiinsa ja pyrkivät hanakasti vahvistamaan niitä entisestään.

"Talouden ensisijaisuus" oli aikakauden toimintakykyisimmille viipurilaisille itsestään selvä periaate. Siksi hankkeet kulttuurin edistämiseksi jäivät koko jaksolla täysin sivuseikoiksi. Viipurilaisten saavutukset henkisen kulttuurin viljelyssä jäivätkin vähäisemmiksi kuin kaupungin yleinen poliittinen ja taloudellinen merkitys olisivat antaneet olettaa; Viipurissa keskityttiin ensi sijassa käytäntöön ja taloudellisten hyveiden vaalimiseen. Puhdasoppisen ajan yleisen ilmapiirin vastaisesti esimerkiksi uskonnollisuus ja kirkko ylipäätään, siinä kuin pappien johtama koululaitoskaan, eivät viipurilaisia suuremmin kiinnostaneet, vaikkei suoranaisia näyttöjä mainittujen instituutioiden ja laitosten halvennuksestakaan toisaalta juuri löydy. Edellä mainittu piispa Bångin voihkaisu aikakauden lopulta lienee lähinnä jyrkkä kärjistys, jollaisiin tosin usein sisältyy totuuden siemen. Tosiasiassa viipurilaisissa kauppiasperheissä oli ollut jo varhain kotiopettajia ja 160o-luvun lopulla kaupunkilaiset halusivat itse kustantaa nimenomaan porvarisammateissa tarvittaviin aineisiin keskittyneen opinahjon.

"Viipurin omalaatuinen kulttuuri" tarkoittikin Ruotsin vallan ajalla ennen muuta talouden ylivaltaa henkisistä riennoista. "Viipurilaisten avaramielisyys ja suvaitsevaisuus suhteessa toinen toisiinsa" puolestaan tarkoitti lähdeaineiston valossa ainakin rehevää kielenkäyttöä ja sukulaisten välisiä kovaäänisiä riitoja. Toisaalta kolikon, tai tässä tapauksessa paremminkin taalerin kääntöpuolen muodostaa havainto siitä, että Viipuri oli 160o-luvulla harvinaisen rauhallinen ja aikakauden mittapuun mukaan myös turvallinen kaupunki. 


\section{Viitteet}

1 Esimerkkejä tutkimuksesta: Meyer \& Myhre 2000; Hentilä 2004; Berger \& Lorenz 2008; Kalela 2012; J. Tilli 2012; Karonen \& Räihä 2014, 15-16 ja siinä mainitut lähteet. Poikkeuksena: Ågren 2011.

2 Tuurna 1958, 7-8.

3 Viipuri valtakunnan "lukkona" eli puolustusmuurina itää vastaan ennen muuta suuren Pohjan sodan (1700-1721) aikana: Karonen 2009. Käsite "lukko" on syntynyt vasta 1600-luvun kuluessa, sillä vielä esimerkiksi 25-vuotisen Venäjän sodan (1570-1595) aikana puhuttiin vain arkipäiväisemmin kaupungin linnoittamisesta ja linnoituksen vahvistamisesta. Visbystä tuli 1600-luvun puolimaissa neljäs linnoitettu kaupunki, kun Ruotsi valloitti Gotlannin Tanskalta. Esim. Hammarström 1982; Karonen 1995, 12; Ahlberg 2005, 25; yleisemmin Karonen \& Villstrand 2014, 150.

4 Åström 1977a, 146-149; Karonen 2014, esimerkiksi 262-263, 279-280.

5 Grotenfelt 1887; Katajala 2010.

6 Jo Gabriel Laguksen (1895) ja J. W. Ruuthin (1908) teokset hyödynsivät laajasti tuomiokirja-aineistoja. Karonen 1994a, passim; Karonen 1995 passim; Karonen 2010. Harvinaisia väläyksiä viipurilaiseen todellisuuteen kruunun virkamiehen näkökulmasta saa maaherra Johan Rosenhanen 1600-luvun puolimaissa kirjoittamasta päiväkirjasta: Rosehane 1995. Tarkemmin esim. Toivanen 1991; Jansson 1995; C. J. Gardberg 1997; Einonen 2011.

7 Konung Gustaf den förstes registratur 1-29; Herlitz 1927; Nygren 1932; Lindberg 1939; Lindberg \& Sleman 1946; Sleman 1964; Corin \& Sleman 1985; Durchman 1928; T. Melander 1951; Kotivuori 2005. Keskiajalta säilyneet asiakirjat löytyvät: Diplomatarium Fennicum -tietokannasta (http://extranet.narc.fi/DF/index.htm). Asiakirjoista suurin osa liittyy tavalla tai toisella Viipurin linnaan tai pormestarin ja raadin kontakteihin eri kaupunkeihin, ennen muuta Tallinnaan.
8 Ruuth \& Halila 1974.

9 Kallioniemi 1993; Forsberg 1993.

10 Kivi-Koskinen 1958; Nissilä 1958a; Nissilä 1958b.

11 G. Lagus 1893; G. Lagus 1895; Ruuth 1906; Ruuth et al. 1982; Ruuth \& Halila 1974; Ruuth et al. 1982; Kaukiainen, Marjomaa, \& Nurmiainen 2010. Kimmo Katajala (ISY) johtaa Suomen Akatemian hanketta (2014-2016) "Kaupunkitilan merkitykset ennen ja nyt. Kulttuurien välinen tutkimushanke Viipurin kaupungista 1500-luvulta 2000-luvulle”, jossa tematiikka saa osakseen monipuolisen tarkastelun.

12 Ruotsin kaupunkipolitiikasta erityisesti Heckscher 1923; Norborg 1963; Sandström 1996; kansainvälisesti esimerkiksi artikkelit teoksessa Blockmans \& Tilly 1994.

13 Niin sanotuista regaalioikeuksista esim. Malcus 1971, 6-7, 10; Vilkuna 1994, 50-51, 290; Karonen 2004, 71.

14 Esim. Ranta 1980; Ranta \& Åström 1980; Ranta 1981.

15 Herlitz 1927, n:ot 64 (19.8.1403), 114 (7.5.1448), 119 (6.6.1449), 255 (10.11.1522); Privilegier, resolutioner och förordningar för Sveriges städer. Andra delen (1523-1560). Utgiven av Ernst Nygren. Stockholm 1932, n:ot 5 (22.9.1523), 18 (19.3.1525), 96 (26.6.1534). Viipurin privilegioista yleiskatsaus: Ruuth 1908, 151, 167-169; Katajala 2010, 25, 28-29.

16 Nygren 1932, n:ot 111 ja 112 (24.7.1537), myös n:o 120 (23.1.1539).

17 Vielä kuningas Sigismundin viitisenkymmentä vuotta myöhemmin vahvistamat Viipurin erioikeudet perustuivat pääsääntöisesti Kustaa Vaasan antamiin privilegioihin. Nygren 1932, n:ot 138 (7.8.1543), 168 (29.7. -11.10.1545), 192 (30.4.1547). Sigismundin privilegioista: Lindberg \& Sleman 1946, n:o 43 (9.7.1594). Markkinoista erityisesti: Qvist 1909.

18 Lindberg 1939, n:o 32 (7.8.1562). 
19 A. Mäkinen 2010, erityisesti kartta sivulla 238; tarkemmin A. Mäkinen 2002; myöhemmiltä ajoilta A. Kujala 2010. Viipurin linnan varusväen määrän muutos kertoo paljon: 1500-luvulla linnassa asusti tavallisesti 600-700 miestä, mutta esimerkiksi Stolbovan rauhan solmimisen jälkeen 1630-luvun alussa enää neljä upseeria ja 40 vahtimiestä. Vuonna 1682 vahvuus oli vain yksi korpraali ja 24 miehistön jäsentä. Ruuth 1908, 254; K. R. Melander 1910, 18; Kiuasmaa 1968, 20.

20 Lindberg 1939, n:o 146 (30.7.1573). Katso myös n:o 182 (12.11.1576), jossa Juhana III kirjoitti pormestarille ja raadille ja totesi näiden pyytäneen "tiettyjen alueiden" kaupan ohjaamista Viipuriin; hallitsijan ympäripyöreä vastaus ei tosin luvannut kuin kaupungin ympärillä olevat naapuripitäjät.

21 Rent seekingistä eli erityisvoitonpyynnistä esimerkiksi J.-A. Lamberg, Ojala, \& Eloranta 1997; R. B. Ekelund \& Tollison 1997; Ojala 1999; J. A. Lamberg 1999; Karonen 2004, luku 5 (jossa myös määritelty käsitteen merkitys ja käyttötavat varhaismodernissa ruotsalais-suomalaisessa yhteiskunnassa).

22 Esivallan ja alamaisten kohtaamista on tutkittu paljon Ruotsissa ja Suomessa. Viimeisimmistä näkemyksistä aihepiirin tutkimukseen esimerkiksi Villstrand 2011; Lindström 2013, 236-237; Ericsson 2013, 257-260; Karonen 2014, 22 ja viitteessä 15 mainittu kirjallisuus.

23 Vuoden 1600 jälkeen Viipurin privilegiot vahvistettiin Ruotsin ajalla vain kolme kertaa, vuosina 1617, 1650 ja 1676. Seuraavan kerran erioikeudet vahvistettiin vasta Venäjän vallan aikana, 1740-luvun alussa. Lindberg \& Sleman 1946, n:o 129 (12.4.1600); Karonen 2013, 69-70.

24 Sleman 1964, n:o 87 (7.2.1616), 91 (8.2.1616). Maapäivistä eloisa esitys: Mirkka Lappalainen 2014.

25 Nygren 1932, n:o 192 (30.4.1547); Lindberg 1939, 71 (19.3.1569); myös esim. Grotenfelt 1887, 100-101; Ruuth 1908, 143. Helsinki vertailukohtana: Aalto 2012.
26 Edellä oleva suurelta osin: Möller 1975, lainaus 168; myös Karonen 2004, 72.

27 KA: Viipurin raastuvanoikeuden tuomiokirjat, 13.8.1688: 458-460; Vilkuna 1994; Karonen 2014, 78.

28 Ruotsin Suomen kaupunkien asukkaista 1700-luvulla kaikkein rohkeimmin valtion tarjoamia etuja käyttivät nimenomaan Viipurista (suuren Pohjan sodan jälkeen) ja Haminasta (hattujen sodan 1741-1743 jälkeen) kotoisin olleet tai mainituissa kaupungeissa pitkään vaikuttaneet porvarit. Osin kyse oli siitä, että kotikaupungistaan Viipurista lähtemään joutuneet kauppiaat uskalsivat kovasanaisesti vaatia valtiota kompensoimaan kärsittyjä tappioita. Osittain kyse oli todennäköisesti kokemuksen tuomasta varmuudesta, jonka myötä he olivat tottuneet vaatimaan suuria, ja myös perustelemaan anomuksen muotoon laaditut kirjoitelmansa vakuuttavasti. Tästä erityisesti: Karonen 2004; Karonen 2013.

29 Lundkvist 1960, 71, 73, 75, 83, 88, 90. Helsingistä: esim. Sandström 1996; Aalto 2012.

30 Grotenfelt 1887, esim. 109, 116; Pohjolan-Pirhonen 1960, 385; Odén 1966, 315; Attman 1973, 70; Attman 1979, 9-14, 142-145 ja passim; Attman 1985; Kuisma 1993; Kotilaine 2004, luku 5 ja 6; Katajala 2010, 158.

31 Tosin tervanvientimäärät vaihtelivat suuresti vuodesta toiseen, minkä lisäksi yllättävän iso osuus tervasta jäi Itämeren piiriin eli sitä ei viety Juutinrauman länsipuolelle. Ruotsin ajan jälkeen Viipurin tervanvienti supistui merkittävästi. Yhtäältä kyse oli siitä, että tuolloin tervaa myytiin isoja määriä suoraan Venäjän laivastolle, eikä tämä myynti näkynyt ulkomaankauppatilastoissa. Toisaalta Uudenkaupungin rauhan raja oli katkonut monet aiemmat ostokanavat. Kolmas, ja tärkein, syy oli se, että viipurilaiset siirtyivät nopeasti ja lopullisesti tervakauppaa tuottoisamman sahateollisuuden pariin. Lindholm 1892, 146-147; Ruuth 1908, 329; Hallberg 1959; Luukko 1967; Ahvenainen 1984; Ranta 1986; Åström 
1988; Villstrand 1992; Kuisma 1993; Karonen 2013.

32 Åke Sandström kutsuu mainittuja viittä kaupunkia puhtaaksiviljellyiksi tapulikaupungiksi: Sandström 1996, 38. Viipurin ja muiden Suomen puoleisen valtakunnan kaupunkien valtiolle tuottamista vero- ja tullituloista 1600-luvun alkupuolella tarkemmin: Lindholm 1892, erityisesti 118-119; Kerkkonen 1945.

33 Tiettävästi ensimmäinen maininta tuolloin aivan uuden nautintoaineen, tupakan, saapumisesta Viipuriin on vuodelta 1642. KA: Viipurin raastuvanoikeuden tuomiokirjat, 15.1.1642.

34 Ranta \& Åström 1980, 285-290; Ranta 1981, 70-71; Nikula 1981, 163-165; Karonen 2013, 86; Karonen 2014, 265-266, 278280 ja siinä mainittu keskustelu.

35 Karonen 2013, 87 (siinä viittaus Kaarle Soikkelin keräämään aineistoon, joka on sijoitettu Mikkelin maakunta-arkistoon).

36 Tästä keskustelusta erityisesti: Åström 1977b, 92-96; Karonen 2014 ja siinä mainittu kirjallisuus.

37 Esimerkiksi Ranta 1979; Ranta 1982; Karonen 2014, 262.

38 Grotenfelt 1887, 124; Ruuth 1908; Lilja 1996, 142.

39 Viipurin henkikirjoihin merkittyjen lukumäärä oli 1600-luvulla suurimmillaan vuoden 1640 tienoilla, jolloin veroa maksavia oli yhteensä yli 2100 henkeä. Tämä vastaa laskutavasta riippuen noin 3500-5 300 asukasta (henkikirjoihin perustuvista väkilukuarvioista: esim. Ruuth 1908; Karonen 1994a; Karonen 2014, 40). Sven Lilja puolestaan arvioi ennen muuta kotitalouksien määrään perustaen Viipurin asukasluvun 1650-luvulla noin 3000 asukkaaksi ja 1690-luvulla noin 2600 hengeksi: Lilja 1996, 2000. Claes Westlingin toteuttama kokonaisvaltainen väkiluvun laskumenetelmän jossa käytetään peruslähteiden lisäksi kaikkia mahdollisia muita aineistoja, tulisi vakavasti sovellettuna lähelle henkikirjaväkiluvun perusteella laskettua korkeinta lukemaa: Westling 2002, erityisesti luku 4.
40 Möller 1954. Venäjän vallan alle siirtymisen jälkeen Viipurin kauppiaiden määrä nousi Ruotsin ajan tilanteesta jonkin verran, vaikka samaan aikaan kaupungin asukasluku väheni. Esimerkiksi 1726 kauppiaita oli yhteensä 42, mikä luku nousi kauppiaiden leskien ja maistraatin kauppaa harjoittavien jäsenten avulla yhteensä 69:ään. Karonen 2013, 75.

41 Esimerkiksi Möller 1954, 100-102; Mäkelä-Alitalo 2008; Auranen 2006; Karonen 2004.

42 Aivotuonnista erityisesti Niléhn 1981; Sandström 1996, 166; Karonen 2003; Karonen 2004.

43 Grotenfelt 1887, 127; Ruuth 1908, 181, 184, 187-189, 191; K. Blomstedt 1921, passim; Schweitzer 2013, 15.

44 Esimerkiksi Juhana-herttua totesi 1558 Viipurin pormestarille ja raadille saksalaisista kauppiaista olleen suurta haittaa porvaristolle. Herttuan mukaan näiden harjoittamaa laitonta tavaroiden ostamista ennakkoon eli etuostoa ei voitu sallia vieraille (fremmande), koska se ei käynyt päinsä omanmaalaisillekaan. Nygren 1932, n:o 272 (2.4.1558). Vrt. Lindberg \& Sleman 1946, 230 (3.7.1607); Sandström 1996, 177-179 (lainaus).

45 Ruuth 1908, 306-307.

46 Esim. KA: Viipurin raastuvanoikeuden tuomiokirjat, 13.12.1652: 113; Karonen 1994a, 90; Karonen 2010; Ruuth 1908, 304.

47 Tässä suhteessa ero Venäjän vallan ajan eli Vanhan Suomen ajan Viipurin osin hyvinkin vaikeasti sisään päästäviin sukulaispiireihin oli merkittävä.

48 Tässä suhteessa tyypillinen on esimerkiksi Ruuthin ja Aimo Halilan otsikointi, josta löytyvät erikseen muun muassa seuraavat käsitteet: "Saksalainen aines", "Ruotsalainen aines", "Muu vierasperäinen aines", "Syntyperäiset viipurilaiset ja taistelu ulkomailla syntyneitä tulokkaita vastaan", "Eräitä kansallistuneita ulkomaisia mahtisukuja: Freset, Schmidtit ja Thesleffit”: J W Ruuth \& Halila 1974, luku 
"Viipurilaiset". Vrt. Tandefelt 2002b, 13 (monikielisten yhteisöjen kielivariaatiot).

49 Möller 1954, 71-72.

50 Tandefelt 2002b, 28; Schweitzer 2013, 16-17.

51 Kustavi Grotenfelt mainitsee kaupungin suurimpien veronmaksajien joukossa vuonna 1559 muun muassa Simo Varttisen, Hinnola Maunun, Multiala Kaarinan ja Ingi Kostiaisen: Grotenfelt 1887, 127.

52 Oikeuslaitoksen aineistossa 1600-luvulta tavataan niukasti mainintoja edes taloudellisista suhteista venäläisiin, joista tosin osa saattoi hyvinkin olla uskonnoltaan ortodoksisia Ruotsin kuninkaan alamaisia. Monet tapauksista olivat erilaisia kauppalainsäädännön rikkomuksia. Esimerkiksi KA: Viipurin kämnerinoikeuden pöytäkirjat, 4.3.1637: 366-367; Viipurin raastuvanoikeuden tuomiokirjat, 27.3.1647. Kruunun pyrkimyksistä valvoa Viipurissa harjoitettua venäläiskauppaa: Nygren 932, n:o 168 (29.7. -11.10.1545), 207 (5.7.1549), 226 (3.12.1552); Lindberg. 1939, n:o 175 (15.5.1576); Lindberg \& Sleman 1946, n:o 28 (27.3.1594), 59 (1.4.1595). Viipurin kieliasioista kootusti: Tandefelt 2002b, 26-29, 32-35

53 Yksi tällaisista tapauksista esiintyi jo vuonna 1635, kun Johan Cröell oli riitautunut silloisen raatimies Hans Schmedemanin kanssa Lappeenrannan markkinoilla. Taustalla oli ajankuvaa hyvin vahvistavasti kiista talonpoikien tervaeristä. Asiasta teki erityisen kiusallista niin Cröellin haukkumasanat, hänen muut koko kaupunkia hallinnutta raastuvanoikeutta kohtaan osoittamansa epäkunnioitus kuin tietenkin myös se, että mesoamista oli kuulemassa suuri joukko porvareita, lähiseutujen talollisia ja muuta kansaa. Sanastoon olivat Schmedemanin kirjallisen valituksen - jonka perussanoman kantajan paikalle kutsumat todistajatkin vahvistivat - kuuluneet sellaiset laatuilmaukset kuin "din hundsesfot, din bewenhyttare, din werewittunpoika”, lisäksi hieman perinteisempää sanastoa edustivat varkaaksi sekä "tärkeäksi” ja "kunnia-arvoisaksi" ironisessa merkityksessä nimittely. Cröellin riitaisuuteen viittaa myös esimerkiksi maaherra Johan Rosenhane usein päiväkirjassaan 1650-luvun alussa. KA: Viipurin raastuvanoikeuden tuomiokirjat, 21.11.1635, 23.11.1635, 25.11.1635; Rosenhane 1995, 31-32, 42; SAOB, bärnhyttare, fuskare. Huldén \& Tandefelt 2002, 124-127.

54 KA: Viipurin raastuvanoikeuden tuomiokirjat, 30.5.1648, 31.5.1648, 18.10.1648.

55 Nils Ahlberg täydentää merkittävästi aiemman tutkimuksen näkemyksiä, vaikka hän ei ole viitannut lainkaan Lagukseen tai Ruuthiin, jotka kummatkin olisivat vieläpä olleet saatavilla ruotsiksi. Ahlberg on laajassa (860 s. + toinen osa karttoja, 196 s.) väitöskirjassaan tutkinut kaikki aikakauden Ruotsin valtakuntaan kuuluneet kaupungit ja niiden kaupunkisuunnitelmat, myös voittomaiden ja provinssien: Ahlberg 2005, 145. Lisäksi asemakaavasta ovat kirjoittaneet muun muassa Meurman sekä taidehistoriallisesta näkökulmasta Gerhard Eimer, kartografian alalta Juhani Kostet ja arkkitehtuurista Marjut Kirjakka: Meurman 1958; Eimer 1961; Kostet 1995; Kirjakka 1996. Rakennusperinnöstä kiinnostavia pitkän linjan näkemyksiä sisältyy teoksiin: Neuvonen 2008; Hyvärinen 2012.

56 Ahlberg 2005; Katajala 2010, 37.

57 Nygren 1932, n:o 130 (12.3.1541).

58 Nygren 1932, n:o 169 (31.71.1545); myös Lindberg \& Sleman 1946, n:o 230 (3.7.1607); esim. Ruuth 1908, 152; Katajala 2010, 72-75.

59 Esim. Nygren 1932, n:o 138 (7.8.1543), 283 (14.6.1559); Lindberg \& Sleman 1946, n:o 204 (30.7.1605).

60 Nygren 1932, n:o 192 (30.4.1547); Lindberg 1939, n:o 7 (13.2.1561).

61 Esim. Lindberg 1939, n:o 7 (13.2.1561, kohta 4), n:o 142 (8.5.1573); n:o 182 (12.11.1576)

62 Lindberg \& Sleman 1946, n:o 52 (30.9.1594); Corin \& Sleman 1985, n:o 203 (28.2.1628; myös kommentaarit); Ruuth 1908, 144; kootusti: Jutikkala 1997, 492-493, 495. 
63 Lindberg 1939, n:o 79 (8.8.1569); Ruuth 1908, 147.

64 Lindberg 1939, n:o 273 (28.2.1583).

65 Sleman 1964, n:o 65 (19.12.1614), 84 (4.2.1616); Ruuth 1908, 146-147.

66 Corin \& Sleman 1985, n:o 203 (28.2.1628, lainaus s. 411); Ruuth 1908, 262.

67 Ruuth 1908, 147.

68 Ruuth 1908, 134-135, 140, 262-263; Lilius 1981, 317.

69 Ruuth 1908, 265; Halila 1942, 200-201; Ranta 1975, 60-61; Lilius 1981, 317; Karonen 2004, 152-153.

70 Karonen 1995, liite 1, kohta 4; Ågren 1998; yleisesti eurooppalaisesta kehityksestä: Friedrichs 1995, esim. 246-247; Clark 2009.

71 Esim. Viipurin kuninkaallisena pormestarina vuosina 1629-1647 toiminut Casper Thile omisti 1649 huonekellon ja Viipurin läänin maaherra Johan Rosenhane puolestaan teki toisinaan tarkkoja muistiinpanoja ajankäytöstään: Rosenhane 1995, esim. 64 (5.4.1653); G. Lagus 1895, 121-122, myös viite 4; Ruuth 1908, 293; Salenius 1911, 49-51; Ruuth \& Halila 1974, 289-290; Karonen 1994b.

72 Erityisesti G. Lagus 1895; Ruuth 1908, 173, 238, 298-299; Ruuth \& Halila 1974 korostavat kaikki oikeusaineiston käsittelyssään eräänlaisia kauhutarinoita ja monenlaisia aikalaisten keskinäisiä konflikteja. Tämä käsitys on siirtynyt lähes sellaisenaan moniin muihinkin esityksiin. Vrt. Vilkuna 2009, jossa analysoidaan muun muassa yksi Viipurissa murheellisesti päättynyt kaksintaistelu.

73 Karonen 2010.

74 Esimerkiksi 1635 raastuvassa käsiteltiin tapausta, jossa pormestari Anthoni Bröijer ja raatimies Hans Schmedeman syyttivät kollegaansa, raatimies-kauppias Herman von Borgenia raastuvanoikeuden muiden viranhoitajien solvaamisesta sekä kantajien kunnian ja maineen pilaamisesta Lappeenrannan markkinoilla. Von Borgen oli vahvassa humalassa muun muassa sanonut Schmedemanille mm. "Kiäre ähra I en rådzherre, Ja en hundesfått, du est jeke (?) et kottehår, eller en hundfitta, bättere än Jagh ähr". Todistajana kuultu raatimies Herman Schmalhorst mainitsi von Borgenin toiselleen fraasia "parempi kuin hän". KA: Viipurin raastuvanoikeuden tuomiokirjat, 14.11.1635. Vastaava raadin sisäinen tapaus esimerkiksi KA: Viipurin raastuvanoikeuden tuomiokirjat, 26.5.1652: 555-559, 1.9.1652: 589-596, 22.9.1652: 602-603, 25.9.1652: 608-609, 27.9.1652: 617.

75 Esim. KA: Viipurin raastuvanoikeuden tuomiokirjat, 14.1.1624 (raatimies Reinhold Boismanin rengin ja piian salavuoteus sekä samana päivänä raatimies Hans Schmidtin rengin ja piian vastaava tapaus); 30.10 .1626 (jälleen raatimies Hans Schmidtin rengin ja piian salavuoteustapaus); 27.11.1626 (raatimies Claus Sidensnören renki ja piika); 20.6.1642 (raatimies Herman von Brokenin renki ja piika); Viipurin kämnerinoikeuden pöytäkirjat vuosilta, 1.2.1637: 364 (tulevan raatimiehen Petter Fresen palvelusväen vastaava tapaus).

76 Halila 1944, 110-116; Ruuth 1908, 304305, myös viite 2, 441-442.

77 Aimo Halila antaa ennen muuta J. W. Ruuthin perusteella eloisan kuvan Moijin kynäilijäurasta: Halila 1944. Moijin paskilleja ovat käsitelleet myös: Huldén \& Tandefelt 2002, 129, 131; Kivistö \& Riikonen 2012; Riikonen 2012; eurooppalaisesta kehityksestä: esim. Friedrichs 2000, 46

78 Ruuth 1908, 416-417, 422; Hanho 1947, 52, 59 (lainaus), 60; Nissilä 1958b, 201202; Klinge 1993. Viipurin hiippakunnan piispoista ja hiippakunnasta erityisesti: Heininen 2007; Heininen 2012a sekä monet pienoiselämäkerrat Svenskt biografiskt lexikonissa, Kansallisbiografiassa ja Biografisk lexikon för Finlandissa.

79 Taulukon 1 luvut ovat korkeampia kuin mitä esim. Aimo Halila esittää ( $N=81)$, joskin Halilan tiedot käsittävät vain vuodet 1661-1710 ja koskevat ilmeisesti vain Turun akatemiaa. Ruuth \& Halila 1974, 347. Samoin John Strömbergin luvut Turun akatemian opiskelijoista poikkeavat tässä esitetyistä, mutta silti hänen perus- 
tuloksensa ei muutu: Viipurin hiippakunta oli ylisummaan koulutuksellista periferiaa. Eino E. Suolahti puolestaan laski Turun kaupungista olleen kotoisin samalla jaksolla yhteensä 330 porvarisylioppilasta. Strömbergin mukaan Turun seudulta Turun akatemiassa opiskeli 1600-luvulla yhteensä 702 opiskelijaa. Strömberg 1996, 72, 77; Suolahti 1946, liite. Opiskelusta ajalla ennen Turun akatemian perustamista erityisesti: Nuorteva 1997.

80 Ensimmäinen tunnettu onnitteluruno oli viipurilaisen pormestari Hans Schmedemanin pojan Johanin ja raatimies Henrik von Brokenin pojan Justinuksen (myöhemmin Viipurin pormestari) laatima onnitteluruno Tarton yliopistossa 1649. T. Melander 1951, n:o 252. Katso näistä tarkemmin: Laine 1997; Laine \& Nyqvist 1996.

81 T. Melander 1951, esim. n:ot 314, 374, 380, 575, 1882, 1977-1979. Uskonnollisista muistokirjoituksista ja ruumissaarnoista erityisesti Stenberg 1998, passim. Porvariston piirissä Ruotsissa ja Suomessa laadituista varhaismodernilla ajalla Karonen 2004, 53-54 ja siinä viitteissä 66-67 mainitut lähteet.

82 Olaus Qvastista tuli myöhemmin Viipurin läänin Uudenkirkon pitäjän kirkkoherra. Henrik Winter puolestaan oli jo valmistuessaan Viipurin triviaalikoulun rehtori ja myöhemmin toimi eri tehtävissä Viipurin lukiossa. Gustaf Berner oli hänkin ensin Viipurin lukion kaunopuheisuuden lehtori ja myöhemmin Hollolan kirkkoherra ja lääninrovasti, joka kuoli isovihan aikana pakolaisena Ruotsissa. Kotivuori 2005; Sihvo 1973, 29.

83 Myös Ruuth 1908, 423.

84 Salenius 1911, 49-51; teosten identifioinnissa on käytetty apuna muun muassa
Henrik-tietokantaa (http://dbgw.finlit.fi/ henrik/index.php) sekä Wikisourcea (https://de.wikisource.org/).

85 Ruuth 1908, 428 (viite); Salenius 1911, 49-51.

86 Systemaattisen tutkimuksen vähäisyyden vuoksi on toistaiseksi vaikea tehdä pitkälle meneviä päätelmiä erityisesti aatelittomien virkamiesten palkkatasosta. Silti nopea analyysi tiliaineistojen niin sanottuihin menosääntöihin (stat) viittaa siihen, että korkeimpien lääni- ja paikallistason virkamiesten palkat sinänsä olivat varsin hyvät. Esimerkiksi tiedot Casper Thilen palkkauksesta ovat hieman epävarmoja, mutta hänen pormestariaikanaan Viipurin kokoisissa ja statukseltaan samantasoisissa kaupungeissa tehtävästä maksettiin tavallisesti noin 300-400 hopeataaleria vuodessa. Carl Thile sai vuonna 1649 vero- ja muonitusmestarin tehtävästä yhteensä 227 hopeataaleria ja edellä toisessa yhteydessä mainitulle kamariviskaali Samuel Cröelille maksettiin 150 taaleri. Viipurin piispan ja maaseudun kirkkoherrojen palkat olivat näitä summia tavallisesti huomattavasti suurempia, mutta Viipurin kaksi kappalaista sai tyytyä hieman yli 50 hopeataalerin rahapalkkaan. Mainittuihin summiin ei sisälly mahdollisia lisäpalkkoja tai -etuuksia, jollaiset olivat aikakaudella yleisiä. Vertailuksi käynee havainto, jonka mukaan samana vuonna Viipurin lukion koko budjetti jäi alle 1900 hopeataalerin. Ruistynnyri maksoi 2,5-3 hopeataaleria, minkä hankkiakseen kokenut käsityöläisammattilainen sai paiskia töitä reilut kaksi viikkoa. KA: Viipurin ja Savonlinnan läänin läänintilikirja 1649 (vol. 8597), 12, 15, 24; Karonen 1995, passim. 